\title{
2-Sulfoethylammonium Trifluoromethanesulfonate as an Ionic Liquid for High Temperature PEM Fuel Cells
}

\author{
K. Wippermann, ${ }^{\mathrm{a}, \mathrm{z}}$ J. Wackerl, ${ }^{\mathrm{a}}$ W. Lehnert, ${ }^{\mathrm{a}, \mathrm{b}, *}$ B. Huber, ${ }^{\mathrm{c}}$ and C. Korte ${ }^{\mathrm{a}}$ \\ ${ }^{a}$ Forschungszentrum Jülich GmbH, Institute of Energy and Climate Research - Fuel Cells (IEK-3), \\ 52425 Jülich, Germany \\ ${ }^{b}$ Modeling in Electrochemical Process Engineering, RWTH Aachen University, Aachen, Germany \\ ${ }^{c}$ Department of Chemistry, Philipps Universität Marburg, 35032 Marburg, Germany
}

\begin{abstract}
2-Sulfoethylammonium trifluoromethanesulfonate $\left(\left[2-\mathrm{Sea}^{+}\right]\left[\mathrm{TfO}^{-}\right]\right)$represents a novel class of proton-conducting ionic liquids (PILs) based on aminoalkylsulfonic acids. The fundamental suitability of $\left[2-\mathrm{Sea}^{+}\right]\left[\mathrm{TfO}^{-}\right]$for application as a protic electrolyte in high temperature PEM fuel cells (HT-PEFCs) was investigated up to a temperature of $130^{\circ} \mathrm{C}$. A comparison was made against a state-of-the-art electrolyte, phosphoric acid. $\left[2-\mathrm{Sea}^{+}\right]\left[\mathrm{TfO}^{-}\right]$is electrochemically and thermally stable up to $140^{\circ} \mathrm{C}$. The specific conductivity of $95 \mathrm{wt} \%\left[2-\mathrm{Sea}^{+}\right]\left[\mathrm{TfO}^{-}\right]$aqueous solution at $130^{\circ} \mathrm{C}$ is $\approx 20$ times lower compared to $95 \mathrm{wt} \% \mathrm{H}_{3} \mathrm{PO}_{4}$. The strong coupling of ion transport and viscous flow suggests a vehicular ion (proton) transport in $\left[2-\mathrm{Sea}^{+}\right]\left[\mathrm{TfO}^{-}\right] .95 \mathrm{wt}^{\circ}\left[2-\mathrm{Sea}^{+}\right]\left[\mathrm{TfO}^{-}\right]$ shows superior kinetics in terms of oxygen reduction reaction (ORR) on polycrystalline Pt compared to $95 \mathrm{wt}_{2} \mathrm{H}_{3} \mathrm{PO}_{4}$ at temperatures greater than $90^{\circ} \mathrm{C}$ in a fuel cell-applicable potential range. Double layer capacitances suggest a complex double layer structure, including adsorbed $\left[2-\mathrm{Sea}^{+}\right]\left[\mathrm{TfO}^{-}\right]$and water, as well as intermediates of oxygen reduction and Pt oxidation. Potential and temperature-dependent ORR kinetics in the presence of $95 \mathrm{wt} \%\left[2-\mathrm{Sea}^{+}\right]\left[\mathrm{TfO}^{-}\right]$yield different Tafel slopes $(\mathrm{b}=82-139 \mathrm{mV})$ and symmetry factors $(\beta=0.46-0.96)$, indicating changes in surface coverages of the adsorbed species and possibly also a change in the reaction mechanism.

(C) The Author(s) 2015. Published by ECS. This is an open access article distributed under the terms of the Creative Commons Attribution Non-Commercial No Derivatives 4.0 License (CC BY-NC-ND, http://creativecommons.org/licenses/by-nc-nd/4.0/), which permits non-commercial reuse, distribution, and reproduction in any medium, provided the original work is not changed in any way and is properly cited. For permission for commercial reuse, please email: oa@electrochem.org. [DOI: 10.1149/2.0141602jes] All rights reserved.
\end{abstract}

Manuscript submitted June 25, 2015; revised manuscript received October 20, 2015. Published November 3, 2015.

Oxygen reduction reaction (ORR) in polymer electrolyte fuel cells (PEFC).- High temperature polymer electrolyte fuel cells (HT-PEFCs) are currently based on phosphoric acid-doped polybenzimidazole-type membranes (PBI) and are operated in a temperature range of $120-180^{\circ} \mathrm{C}$. HT-PEFCs have several advantages over low temperature PEFCs, such as: easier water and heat management, the possibility of recovering high-grade waste heat, a more compact cooling system and a higher $\mathrm{CO}$ tolerance by the anode catalyst.

However, a major drawback of HT-PEFCs is the sluggish oxygen reduction reaction (ORR) kinetics in the presence of phosphoric acid. This is primarily caused by three effects:

(i) The inhibition effect of phosphoric acid on the ORR because of the poisoning of the Pt catalyst due to the adsorption of the $\mathrm{H}_{3} \mathrm{PO}_{4}$ species onto active catalyst sites.

(ii) The low solubility of oxygen in phosphoric acid.

(iii) The slow diffusion of oxygen through the film of phosphoric acid which covers the platinum catalyst.

The adsorption of phosphate by platinum has been studied for more than 30 years $^{1-15}$ by means of cyclic voltammetry $(\mathrm{CV}),{ }^{2-5,9,11-14,16-21}$ rotating disc electrode measurements (RDE), ${ }^{2-5,8,9,11,13,14}$ electrochemical impedance spectroscopy (EIS), ${ }^{13,16,22}$ transient measurements, ${ }^{9,23,24}$ Fourier transform infrared spectroscopy (FTIR), ${ }^{20,25-27}$ electrochemical quartz crystal microbalance $(\mathrm{QCM}),{ }^{18}$ radio tracer experiments, ${ }^{28} \mathrm{X}$-ray photoelectron spectroscopy (XPS) ${ }^{17}$ and X-ray absorption spectroscopy (XAS). ${ }^{14,15}$ The in-operando XAS measurements recently published by Kaserer et al. show the adsorption behavior of $\mathrm{H}_{3} \mathrm{PO}_{4}$ species on $\mathrm{Pt} / \mathrm{C}$ fuel cell cathode catalysts in the temperature range of $50-170^{\circ} \mathrm{C}$ under the operating conditions of an HT-PEFC. ${ }^{15}$

In diluted aqueous solutions and at moderate temperatures, sulphuric acid and sulfonic acids like methanesulfonic acid (MSA) or trifluoromethanesulfonic acid (triflic acid, TFMSA) have been found to be less poisonous than phosphoric acid because sulfonate groups are less strongly adsorbed on $\mathrm{Pt}^{3,29,30}$ For example, Zelenay et al., ${ }^{29}$ in a comparative study of phosphoric acid and TFMSA, showed that
$0.02 \mathrm{M}$ TFMSA is indeed less strongly adsorbed by comparison to $0.02 \mathrm{M}$ phosphoric acid at room temperature. However, the free space available for oxygen reduction is found to be similar at elevated temperatures and for concentrated solutions. ${ }^{29}$ Under these conditions, the advantage of TFMSA lies in its higher oxygen solubility and diffusivity rather than its poisoning effect. ${ }^{29}$ Although this result cannot be generalized, it still indicates the importance of oxygen solubility and the diffusion coefficient of oxygen in the electrolyte being used.

Proton conducting ionic liquids (PIL).- With respect to alternative electrolytes for HT-PEFCs, proton-conducting ionic liquids (PILs) appear to be suitable, as they do not rely on solvents like water. Moreover, PILs typically exhibit good thermal stability, low volatility and low flammability. A suitable PIL, which could be considered a substitute for phosphoric acid in a HT-PEFC, should meet the following requirements:

(i) Weakly coordinating anion to reduce the interaction between the electrolyte and the electrochemically-active sites on the noble metal's (platinum) surface.

(ii) Sufficiently high specific proton conductivity of more than 0.01 $\mathrm{S} / \mathrm{cm}$ in the temperature range between 120 and $200^{\circ} \mathrm{C}$. In order to allow for fast ionic transport, the viscosity should not be too high, i.e. on the order of $10 \mathrm{mPa} \mathrm{s}(\mathrm{cP})$ if no cooperative proton conduction mechanism is present (only vehicle transport). ${ }^{\mathrm{d}}$

(iii) Sufficient solubility and diffusion of oxygen in the PIL to enable fast oxygen transport to the active sites.

(iv) Electrochemically stable in a potential range of $0-1.3 \mathrm{~V}$ vs. NHE

(v) Thermally stable at the maximum operational temperature $\left(120-200^{\circ} \mathrm{C}\right)$

A PIL is generally formed by the protonating of an (organic) base $\mathrm{B}$ by a strong acid HA. The general reaction scheme can be written as follows:

$$
\mathrm{B}+\mathrm{HA} \rightleftarrows \mathrm{BH}^{+}+\mathrm{A}^{-}
$$


In the case of "super acids" like triflic acid $\left(\mathrm{CF}_{3} \mathrm{SO}_{3} \mathrm{H}\right)$, the anion $\mathrm{A}^{-}$(conjugated base) only has a very weak basicity and negligible nucleophilicity. The acidity of the cation $\mathrm{BH}^{+}$(conjugated acid) depends on the strength of the base, B. For a strong interaction with PBI to immobilize the PIL in the membrane, comparable to phosphoric acid, the acidity of the PIL should be sufficient to protonate the benzimidazole groups of the polymer. Thus, for an acidic PIL, preferentially weak bases B have to be considered.

As was recently emphasized by Mamlouk et al., ${ }^{31}$ the proton conductivity of PILs is usually only a fraction of the overall ionic conductivity. Unlike Nafion for instance, counter anions are not fixed within a polymer matrix. Hence, the proton transference numbers $t^{+}$of about 0.5 are the rule rather than the exception. ${ }^{32-34}$ As discussed by Yasuda et al., ${ }^{35} t^{+}$values smaller than 1 not only reduce proton conductivity, but also cause additional polarization through the buildup of concentration gradients in the electrolyte. In a protic electrolyte, the proton charge transfer may, in principle, take place through two mechanisms:

(i) Cooperative proton charge transfer by means of successive proton transfers between an acid and its conjugated base or a base and its conjugated acid. The existence of this mechanism is a prerequisite for exceptionally high proton conductivities. The proton transfers require only slight conformational rearrangements (rotations) of the proton-carrying ions (the "Grotthusmechanism").

(ii) Vehicular proton transfer by drift (or diffusion) of a protonated species. The resulting proton conductivities are considerably smaller by comparison to i) because of the strong coupling between ionic motion and viscous rearrangements.

In pure PILs, prepared using a 1:1 ratio between base $B$ and acid HA, only a vehicular mechanism is usually possible for proton transport. ${ }^{36}$ In the case of a large difference in acidity between the acid $\mathrm{HA}$ and the cation $\mathrm{BH}^{+}$the re-protonation of the anion $\mathrm{A}^{-}$ will not be significant (see Eq. 1). No cooperative proton transfers are possible. A cooperative mechanism will gain importance if an excessive quantity of the base $\mathrm{B}$ or another proton acceptor is added. Cooperative proton transfers between the cation $\mathrm{BH}^{+}$and the excess base $\mathrm{B}$ will increasingly contribute to total conductivity. However, following the fuel cell reaction scheme proposed by Yasuda et al., ${ }^{35}$ the Brønsted base B is generated at the cathode, together with water:

$$
\begin{array}{cc}
\text { Anode : } & \mathrm{H}_{2}+2 \mathrm{~B} \rightarrow 2 \mathrm{BH}^{+}+2 \mathrm{e}^{-} \\
\text {Cathode : } & 1 / 2 \mathrm{O}_{2}+2 \mathrm{BH}^{+}+2 \mathrm{e}^{-} \rightarrow \mathrm{H}_{2} \mathrm{O}+2 \mathrm{~B}
\end{array}
$$

This means that under fuel cell conditions, the base B as well as the amphoter $\mathrm{H}_{2} \mathrm{O}$ is continually produced at the cathode, improving proton conductivity.

Several PILs have been proposed as alternative electrolytes for PEFCs at operation temperatures $>100^{\circ} \mathrm{C} .^{31-33,37-46}$ Most of these PILS consist of protonated cations of large organic bases, e.g. imidazole ${ }^{33}$ and imidazolium derivatives like $\left[\mathrm{EMIm}^{+}\right.$] (1-ethyl-3-methylimidazolium) ${ }^{38} \quad\left[\mathrm{DMOIm}^{+}\right]$(2,3-dimethyl-1octylimidazolium $),{ }^{42,43}$ [MMIm ${ }^{+}$] (1-H-3-methylimidazolium, also referred to as $\left.\left[\mathrm{h}-\mathrm{mim}^{+}\right]\right),{ }^{40,45}$ pyridinium derivatives like $\left[\mathrm{TMDP}^{+}\right]$ (4,40-trimethylenedipyridine) ${ }^{44}$ pyrrolidinium derivatives like $[\text { EMPyr+] (N-ethyl-N-methylpyrrolidinium })^{39}$ and alkylammonium derivatives like $\left[\mathrm{Dema}^{+}\right]$(diethylmethylammonium). ${ }^{41,46}$ Superacids with large, weakly coordinating anions like $\left[\mathrm{TfO}^{-}\right]$ (trifluoromethanesulfonic acid, TFMSA) $)^{41,46}$ and $\left[\mathrm{Tf}_{2} \mathrm{~N}^{-}\right]$(bis(trifluoromethanesulfonyl)imide, [TFSI] $)^{33,43,45}$ are favorably used as protonating agents. Other anions of acids used include, e.g., $\left[\mathrm{HF}_{\mathrm{n}} \mathrm{F}^{-}\right]$ (fluorohydrogenate), ${ }^{38}\left[\mathrm{CH}_{3} \mathrm{SO}_{3}{ }^{-}\right]$(methane sulfonate) ${ }^{40}$ and $\left[\mathrm{BF}_{4}{ }^{-}\right]$ (tetrafluoroborate)..$^{40}$

Principally, the PILs can be either absorbed by a porous matrix (analogous to phosphoric acid in PAFCs) or immobilized in a (polymer) membrane (application in PEFCs). The latter concept can be realized in two ways: (i) Gelation of the electrolyte with a polymer, e.g. HEMA (hydroxyethylmethacrylate), ${ }^{39}$ PVdF-HFP (polyvinylidenefluoride-co-hexafluoropropylene). ${ }^{42,43}$

(ii) Adsorption of an electrolyte/PIL due to an acid-base reaction with an acidic or basic polymer like Nafion, SPI (sulfonated polyimides), ${ }^{41,46} \mathrm{~S}_{\mathrm{n}} \mathrm{MB}_{\mathrm{m}}$ (poly(styrenesulfonate-bmethylbutylene)) or PBI. ${ }^{31,45}$ Ionic charges were formed on the polymer chain by means of a direct protonation with an acidic electrolyte $\left(\mathrm{PBI}+\mathrm{H}_{3} \mathrm{PO}_{4}\right)$ or by prior deprotonation with additional/excess base (Nafion, $\mathrm{SPI}, \mathrm{S}_{\mathrm{n}} \mathrm{MB}_{\mathrm{m}}$ ).

In the case of ii), the ionic liquids can be incorporated into suitable polymers by means of solution casting, starting from a mixture of the ionic liquid and the polymer solution, ${ }^{31,40-43,46}$ or by impregnating the entire membrane with the ionic liquid. ${ }^{45}$ While the conductivity of almost all PILs or PIL/polymer composites has been measured at temperatures up to $120-200^{\circ} \mathrm{C}$, only a limited number have been electrochemically characterized at temperatures higher than $100^{\circ} \mathrm{C}$ (see e.g. Refs. 31, 39, 41, 44, 45).

Proton conducting ionic liquids with zwitterionic cation.- - Our approach is based on aminoalkylsulfonic acids, $\mathrm{H}_{2} \mathrm{~N}\left(\mathrm{CH}_{2}\right)_{\mathrm{n}} \mathrm{SO}_{3} \mathrm{H}$, as potential candidates for the Brønsted base $\mathrm{B}$. These compounds exist virtually only in the tautomeric form, i.e. as a zwitter ion. A well-known example is taurine $\mathrm{H}_{3} \mathrm{~N}^{+}-\mathrm{CH}_{2}-\mathrm{CH}_{2}-\mathrm{SO}_{3}{ }^{-}$(2-aminoethanesulfonic acid). ${ }^{47,48}$-aminoethanesulfonic acid can act as a proton donor and acceptor:

$\mathrm{H}_{3} \mathrm{~N}^{+}-\left(\mathrm{CH}_{2}\right)_{2}-\mathrm{SO}_{3} \mathrm{H} \rightleftarrows \mathrm{H}_{3} \mathrm{~N}^{+}-\left(\mathrm{CH}_{2}\right)_{2}-\mathrm{SO}_{3}{ }^{-}+\mathrm{H}^{+} \quad \mathrm{pK}_{\mathrm{s}, 1}=1.5^{47}$

$\mathrm{H}_{3} \mathrm{~N}^{+}-\left(\mathrm{CH}_{2}\right)_{2}-\mathrm{SO}_{3}{ }^{-} \rightleftarrows \mathrm{H}_{2} \mathrm{~N}-\left(\mathrm{CH}_{2}\right)_{2}-\mathrm{SO}_{3}{ }^{-}+\mathrm{H}^{+} \quad \mathrm{pK}_{\mathrm{s}, 2}=8.74 \quad[4]$

Due to its amphoteric behavior, 2-aminoethansulfonic acid can react with very strong acids, e.g. the "super acid" trifluoromethanesulfonic $\left(\mathrm{CF}_{3} \mathrm{SO}_{3} \mathrm{H}, \mathrm{TfOH}\right)$, by forming (acidic) ionic salts, respectively ionic liquids:

$$
\mathrm{H}_{3} \mathrm{~N}^{+}-\left(\mathrm{CH}_{2}\right)_{2}-\mathrm{SO}_{3}{ }^{-}+\mathrm{TfOH} \rightarrow \mathrm{H}_{3} \mathrm{~N}^{+}-\left(\mathrm{CH}_{2}\right)_{2}-\mathrm{SO}_{3} \mathrm{H} \cdot \mathrm{TfO}^{-}
$$

In the following, 2-sulfoethylammonium trifluoromethanesulfonate will be referred to as $\left[2-\mathrm{Sea}^{+}\right]\left[\mathrm{TfO}^{-}\right]\left(2-\mathrm{Sea}^{+}=2\right.$ sulfoethylammonium). In the literature, only one other study on compounds with a $2-\mathrm{Sea}^{+}$cation could be found. Using $\mathrm{HF} / \mathrm{SbF}_{5}$ as a protonating agent, the hexafluoroantimonate $\left[2-\mathrm{Sea}^{+}\right]\left[\mathrm{SbF}_{6}{ }^{-}\right]$is obtained. $^{49}$

In this experimental study, we compare the physico-chemical and electrochemical properties of 2-sulfoethylammonium trifluoromethanesulfonate and phosphoric acid as protic electrolytes. The effect of the electrolyte (either $\left[2-\mathrm{Sea}^{+}\right]\left[\mathrm{TfO}^{-}\right]$or $\mathrm{H}_{3} \mathrm{PO}_{4}$ ) and temperature on the oxygen reduction reaction (ORR) on polycrystalline platinum electrodes is particularly focused upon. Additionally, the thermal behavior, viscosity and specific conductivity of the electrolytes is compared. The aim of this study is to examine the potential of $\left[2-\mathrm{Sea}^{+}\right]\left[\mathrm{TfO}^{-}\right]$for the replacement of phosphoric acid in HT-PEFCs.

In comparison to aliphatic or aromatic amines, zwitterionic bases only have the advantage of less volatility because of stronger intermolecular forces. This is of special importance if the PIL $\left(\mathrm{BH}^{+} \mathrm{A}^{-}\right)$is mixed with excessive $\mathrm{B}$ to also enable co-operative proton transport, leading to an increase in specific conductivity. If an eutectic exists in the (pseudo-)binary system $\mathrm{BH}^{+} \mathrm{A}^{-}-\mathrm{B}$, the decreased melting point would be an additional benefit. Both effects have been reported by Noda et al. for eutectic mixtures of bis(trifluoromethanesulfonyl)imide $\left(\mathrm{Tf}_{2} \mathrm{NH}\right)$ and imidazole $(\mathrm{Im}) .{ }^{33} \mathrm{Sul}$ fonate based compounds like aminoalkylsulfonic acids (here: compound B) appear to be advantageous, as explained above. ${ }^{3,29,30}$ For the same reasons, strong sulfonic acids (here: compound HA) like TFMSA or TFSI seem to be suitable as compound HAs. 


\section{Experimental}

Electrolytes. - In the course of fuel cell operation, the presence of water is unavoidable because it is produced on the cathode (see also Eq. 2b). At an operating temperature of $160^{\circ} \mathrm{C}$, synchrotron radiography measurements of HT-PEFC MEAs resulted in average phosphoric acid water contents of 4.5-14.6 vol\%, depending on current density. ${ }^{50}$ These values correspond to mass percentages of about 2.6-8.6 wt \% In this work, a medium value of $5 \mathrm{wt} \%$ water was chosen, i.e. electrolytes with $95 \mathrm{wt} \% \mathrm{H}_{3} \mathrm{PO}_{4}$ and $95 \mathrm{wt} \%$ [2-Sea ${ }^{+}\left[\mathrm{TfO}^{-}\right]$were prepared. Given the small electrode surface used in this work $\left(0.29 \mathrm{~cm}^{2}\right.$, see Electrochemical measurements section) and the resulting small currents of up to $\approx 100 \mu \mathrm{A}$, changes of the water content as a result of faradaic processes (i.e., water production by ORR) are negligible. This differs from the conditions in porous MEA electrodes, where the water content of electrolytes increases with rising currents. ${ }^{50}$ Because the physico-chemical properties of highly concentrated electrolytes, namely specific conductivity, viscosity, oxygen solubility and diffusivity, are sensitive to changes to the electrolyte's composition, a change of the electrolyte's properties affects the electrolytic double layer and the faradaic processes of the $\mathrm{Pt}$ surface.

$95 \mathrm{wt} \% \mathrm{H}_{3} \mathrm{PO}_{4}$ - - (i) $15 \mathrm{ml}$ of $85 \mathrm{wt} \% \mathrm{H}_{3} \mathrm{PO}_{4}$ (Orthophosphoric acid "Suprapur," Merck KGaA) was heated in a climate chamber (WK3$600 / 40$, Weiss Umwelttechnik) for $2 \mathrm{~h}$ at a temperature of $160^{\circ} \mathrm{C}$ under dry conditions $(\mathrm{RH}=0 \%)$ and with a nitrogen flow of $10 \mathrm{ml} / \mathrm{min}$ until a composition of $96-98 \mathrm{wt} \% \mathrm{H}_{3} \mathrm{PO}_{4}$ was achieved, (ii) the water content was measured using Karl Fischer Titration (852 KF Titrando, Metrohm), (iii) an appropriate amount of water was added and the solution thoroughly mixed to obtain $\approx 11 \mathrm{ml}(\approx 21 \mathrm{~g})$ of $95 \mathrm{wt} \%$ $\mathrm{H}_{3} \mathrm{PO}_{4}$.

$95 w t \%\left[2-\mathrm{Sea}^{+}\right]\left[\mathrm{TfO}^{-}\right] .-$First of all, $\left[2-\mathrm{Sea}^{+}\right]\left[\mathrm{TfO}^{-}\right]$is prepared as follows: (i) $10 \mathrm{ml}$ of trifluoromethanesulfonic acid (reagent grade, $98 \%$, Sigma Aldrich) was added slowly, while stirring, to $13.9 \mathrm{~g}$ of 2-aminoethanesulfonic acid (taurine), $\geq 99 \%$, Sigma Life Science), (ii) the mixture was stirred at a temperature of $80^{\circ} \mathrm{C}$ for $1 \mathrm{~h}$, (iii) the resulting taurine trifluoromethanesulfonate $\left(\left[2-\mathrm{Sea}^{+}\right]\left[\mathrm{TfO}^{-}\right]\right.$, see the reaction scheme in Eq. 5) was hot filled in a $20 \mathrm{ml}$ tin and sealed. The yield was $>99 \%$ equivalent to a mass of $\approx 31 \mathrm{~g}$ and volume of $\approx 17 \mathrm{ml}$. $\left[2-\mathrm{Sea}^{+}\right]\left[\mathrm{TfO}^{-}\right]$is a colorless, clear liquid with a density of 1.818 $\mathrm{g} * \mathrm{~cm}^{-3}$ at room temperature. Because $\left[2-\mathrm{Sea}^{+}\right]\left[\mathrm{TfO}^{-}\right]$is strongly hygroscopic (like phosphoric acid) and forms a white crystalline solid through reaction with atmospheric moisture or traces of water, it has to be stored under dry conditions.

Secondly, $95 \mathrm{wt} \%\left[2-\mathrm{Sea}^{+}\right]\left[\mathrm{TfO}^{-}\right]$was prepared by the addition of water: (i) about $5.8 \mathrm{~g}$ of $\left[2-\mathrm{Sea}^{+}\right]\left[\mathrm{TfO}^{-}\right]$is poured into the Pt crucible used for the electrochemical measurements (see the next section), (ii) when the appropriate amount of water, typically about $300 \mu l$, is added, a white, milky liquid with solid particles develops, most probably hydrates of $\left[2-\mathrm{Sea}^{+}\right]\left[\mathrm{TfO}^{-}\right]$(see above), (iii) the mixture is stirred with a glass rod, (iv) the mixture was heated up to $130^{\circ} \mathrm{C}$ and then immediately cooled down to $30^{\circ} \mathrm{C}$, resulting in a colorless, clear liquid that can be used for electrochemical experiments.

Electrochemical measurements.-Measuring cells and electrodes.-2- and 3-electrode measurements were performed in a temperature range of $30-130^{\circ} \mathrm{C}$ and under ambient pressure for both $95 \mathrm{wt} \%\left[2-\mathrm{Sea}^{+}\right]\left[\mathrm{TfO}^{-}\right]$and $95 \mathrm{wt} \% \mathrm{H}_{3} \mathrm{PO}_{4}$. To avoid the preparation of large quantities of PILs, the measuring cell was designed for an electrolyte volume in the range of 3-4 ml. Fig. 1 displays the in-house-designed measuring cell developed especially for this purpose. A cylindrical Pt crucible (99.5\%, Heraeus Materials Technology $\mathrm{GmbH} \& \mathrm{Co}$. KG) with a diameter of $20 \mathrm{~mm}$, height of $30 \mathrm{~mm}$ and wall thickness of $0.7 \mathrm{~mm}$ served as both the reaction vessel and counter electrode. It was therefore placed in an electrically insulating PTFE cover which was then sealed with a PTFE lid. The lid had 5 holes ( $\varnothing=3 \mathrm{~mm}$ each) for gas inlet, gas outlet, working electrode, reference electrode and thermo element.

The working electrode was made of a $\mathrm{Pt}$ wire with a diameter of $1 \mathrm{~mm}(99.95 \%$, Goodfellow $\mathrm{GmbH})$ that was fused into a glass tube.

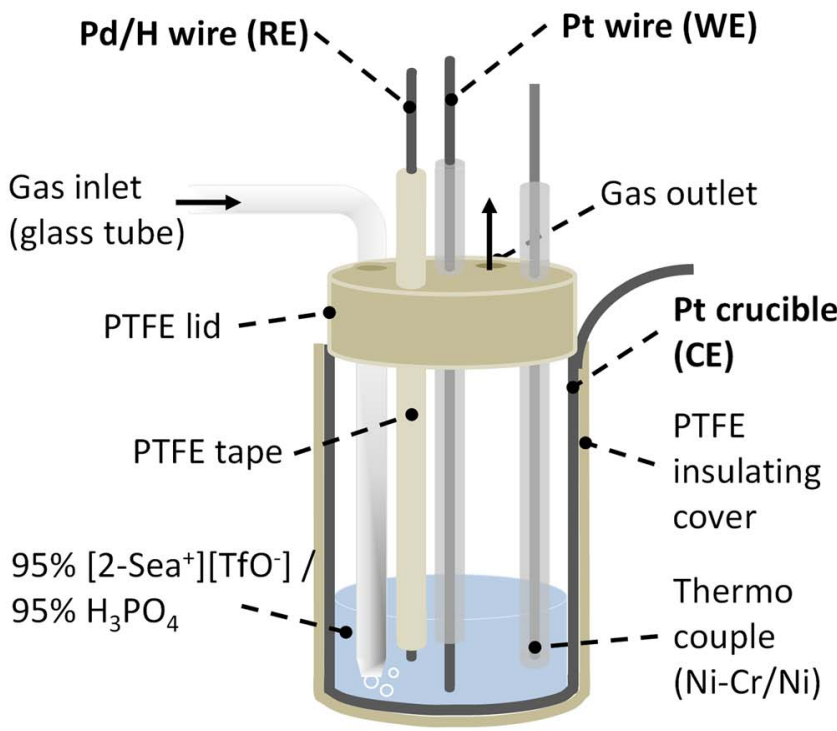

(a)

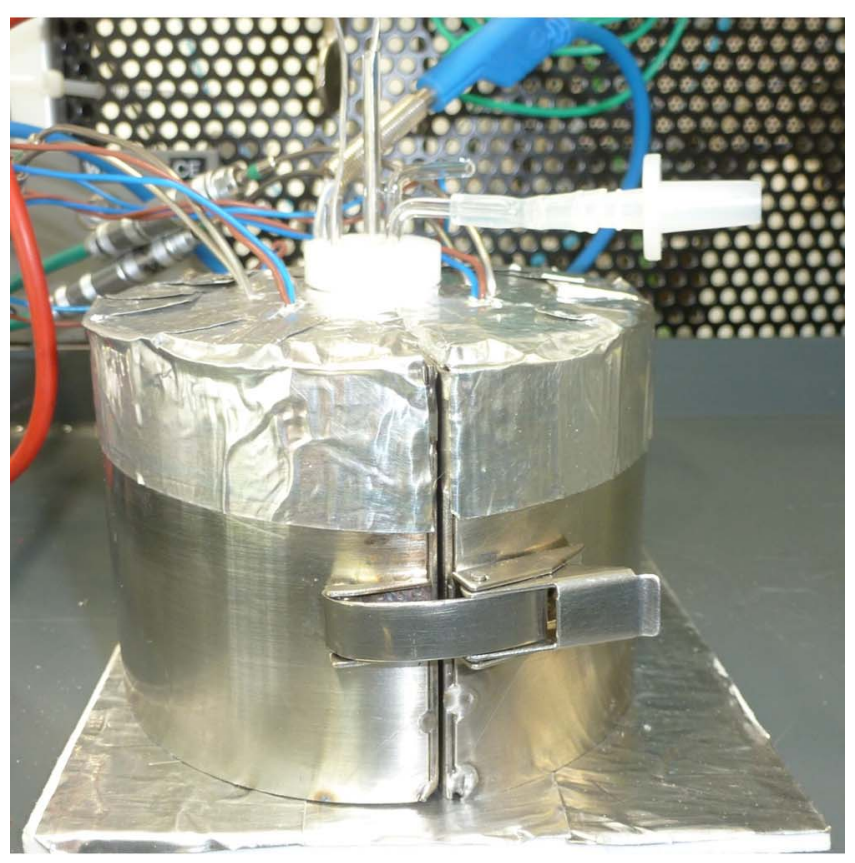

(b)

Figure 1. a. Schematic drawing of the test cell, b. Photograph of the heating device including the test cell.

The Pt wire protruded $7 \mathrm{~mm}$ from the tip of the glass tube, resulting in a geometric surface area of $0.228 \mathrm{~cm}^{2}$. To avoid electric point effects, the wire tip was round polished, using $\mathrm{SiC} 1200$ paper $(14 \mu \mathrm{m})$. The roughness factor of the Pt surface was determined at $30^{\circ} \mathrm{C}$ by means of cyclic voltammetry using $0.5 \mathrm{M} \mathrm{HClO}_{4}$ (made from 67$72 \% \mathrm{HClO}_{4}$ for trace analysis, Fluka Analytical) as the electrolyte. After correction for double layer charging, a hydrogen desorption charge density of $267 \mu \mathrm{C} / \mathrm{cm}^{2}$ was obtained. This value was then divided by the commonly accepted value for smooth polycrystalline Pt electrodes of $210 \mu \mathrm{C} / \mathrm{cm}^{2}$ (see e.g., Brummer et al. ${ }^{51}$ ) and yielding a roughness factor of 1.27 and actual Pt electrode surface of $0.29 \mathrm{~cm}^{2}$.

A self-prepared palladium-hydrogen electrode (referred to hereinafter as a Pd-H electrode) made of a $1 \mathrm{~mm}$ Pd wire $(99.95 \%$, Goodfellow $\mathrm{GmbH}$ ) was used as a reference electrode instead of 
commercially available reference hydrogen electrodes. This was because the latter are too large to be used in our small test cell in cases where 3-electrode measurements are performed with a circular geometry of working and counter electrodes. The tip of the Pd wire was round polished in the same way as the Pt wire. The Pd-H electrode was prepared in a common glass cell filled with $1 \mathrm{M}$ sulfuric acid solution. The preparation temperature was $30^{\circ} \mathrm{C}$. During the preparation procedure, the $\mathrm{Pd}$ wire was operated as a working electrode and separated from the counter electrode (Pt sheet) by a glass frit. The 3-electrode arrangement was completed by a "HydroFlex" hydrogen reference electrode (Gaskatel $\mathrm{GmbH})$.

Preparation of the Pd-H reference electrode closely followed the procedure described in the literature,${ }^{52-54}$ which consists of the following steps: (i) filling of the Pd with hydrogen (with a current density of $-2 \mathrm{~mA} \mathrm{~cm}^{-2}$ for 13 hours), (ii) removal of excess hydrogen (current density of $+10 \mathrm{~mA} \mathrm{~cm}^{-2}$ for 30 minutes), (iii) thorough rinsing the wire with Millipore water and drying by air, (iv) wrapping a thin PTFE foil tightly around the Pd wire and leaving $1 \mathrm{~mm}$ of the tip uncovered. The as-prepared Pd-H electrode has a potential of $50 \pm 1 \mathrm{mV}$ vs. RHE. This potential is stable over more than 24 hours at room temperature. At elevated temperatures of more than $120^{\circ} \mathrm{C}$, stable potentials can still be obtained for several hours. This is possible because the equilibrium of the $\alpha$ and $\beta$ phases of $\mathrm{Pd}-\mathrm{H}$ yields a potential plateau over a broad range of the $\mathrm{H} / \mathrm{Pd}$ atomic ratio.

As is known from the literature, the potential of a $\mathrm{Pd}-\mathrm{H}$ electrode decreases almost linearly with a rising temperature with a slope $(-\mathrm{d} U / \mathrm{d} T)_{\mathrm{p}}$ of $0.5-0.65 \mathrm{mV} /{ }^{\circ} \mathrm{C} .{ }^{54-58}$ However, these results were obtained with diluted aqueous electrolytes, the measurements at $T>$ $100^{\circ} \mathrm{C}$ being performed under pressurized conditions. To our knowledge, the use of a $\mathrm{Pd}-\mathrm{H}$ electrode as a reference electrode in highly concentrated electrolytes under ambient pressure and at elevated temperatures has never been investigated. Hence, the temperature dependent potential of the $\mathrm{Pd}-\mathrm{H}$ reference electrode under these conditions is unknown. To solve this problem, we measured the open circuit potential $\left(U_{\mathrm{Pd}-\mathrm{H}}(\mathrm{RHE})=U_{\mathrm{Pd}-\mathrm{H}}-U_{\mathrm{RHE}}\right)$ of a freshly prepared $\mathrm{Pd}-\mathrm{H}$ electrode vs. a HydroFlex hydrogen reference electrode in the same solution, i.e., either $95 \mathrm{wt} \%\left[2-\mathrm{Sea}^{+}\right]\left[\mathrm{TfO}^{-}\right]$or $95 \% \mathrm{H}_{3} \mathrm{PO}_{4}$, under the same conditions (temperature, time) as for the electrochemical measurements. Unlike the 3 -electrode experiments (see above), this 2-electrode measurement can be performed without any problem. Potential measurements in the range of $30-130^{\circ} \mathrm{C}$ in steps of $20^{\circ}$ yielded temperature dependencies of the OCVs with the following linear regression equations:

$95 w t \%\left[2-\mathrm{Sea}^{+}\right]\left[\mathrm{TfO}^{-}\right]$:

$$
U_{\mathrm{Pd}-\mathrm{H}}(\mathrm{RHE}) / \mathrm{mV}=24.29435 \pm 2.01425
$$

$$
-\left(0.20229 \pm 0.02279 * T /{ }^{\circ} \mathrm{C}\right)
$$

$95 w \% \mathrm{H}_{3} \mathrm{PO}_{4}$ :

$$
\begin{aligned}
U_{\mathrm{Pd}-\mathrm{H}}(\mathrm{RHE}) / \mathrm{mV}= & 17.44386 \pm 0.48528 \\
& -\left(0.12429 \pm 0.00558 * T /{ }^{\circ} \mathrm{C}\right)
\end{aligned}
$$

The resulting $U_{\mathrm{Pd}-\mathrm{H}}(\mathrm{RHE})$ values are listed in Table I. As can be seen, similar $U_{\mathrm{Pd}-\mathrm{H}}(\mathrm{RHE})$ values were obtained for $\left[2-\mathrm{Sea}^{+}\right]\left[\mathrm{TfO}^{-}\right]$and $\mathrm{H}_{3} \mathrm{PO}_{4}$. It is obvious that $U_{\mathrm{Pd}-\mathrm{H}}$ (RHE), ranging from about $0-20 \mathrm{mV}$ is lower than the typical value of $50 \mathrm{mV}$ determined in aqueous solutions and the slopes $(-\mathrm{d} U / \mathrm{d} T)_{\mathrm{p}}$ of $\sim 0.12 \mathrm{mV} /{ }^{\circ} \mathrm{C}$ and $\sim 0.2 \mathrm{mV} /{ }^{\circ} \mathrm{C}$ are also lower than those reported in the literature $\left(0.5-0.65 \mathrm{mV} /{ }^{\circ} \mathrm{C}\right) .{ }^{54-58}$ For the 3-electrode measurements using the $\mathrm{Pd}-\mathrm{H}$ wire as a reference electrode, the potential of the Pt working electrode vs. RHE was obtained by simply adding the measured potentials and values listed in Table I. The latter were also used to calculate the initial and final potentials used in the cyclic voltammograms and polarization curves for each temperature.

Measuring devices.-All of the electrochemical experiments were performed by means of a "Zennium" electrochemical workstation (ZAHNER Elektrik GmbH). The flow rate of the gas feed (air or nitrogen) was adjusted with Brooks mass flow controllers (model

\begin{abstract}
Table I. Potential of the Pd-H reference electrode vs. RHE, values obtained from linear fitting of $\mathrm{OCV}$ measurements in the range of $30-130^{\circ} \mathrm{C}$, with either $95 \mathrm{wt} \%\left[2-\mathrm{Sea}^{+}\right]\left[\mathrm{TfO}^{-}\right]$or $95 \mathrm{wt} \% \mathrm{H}_{3} \mathrm{PO}_{4}$ as electrolyte.
\end{abstract}

\begin{tabular}{ccc} 
& \multicolumn{2}{c}{$\mathrm{U}_{\mathrm{Pd}-\mathrm{H}}(\mathrm{RHE}) / \mathrm{mV}$} \\
\cline { 2 - 3 } $\mathrm{T} /{ }^{\circ} \mathrm{C}$ & $95 \mathrm{wt} \%\left[2-\mathrm{Sea}^{+}\right]\left[\mathrm{TfO}^{-}\right]$ & $95 \mathrm{wt} \% \mathrm{H}_{3} \mathrm{PO}_{4}$ \\
\hline 30 & 18 & 14 \\
50 & 14 & 11 \\
70 & 10 & 9 \\
90 & 6 & 6 \\
110 & 2 & 4 \\
130 & -2 & 1
\end{tabular}

"5850S"). The temperature was set by an in-house-designed heating unit consisting of a temperature controller and a folding steel cylinder equipped with four heating cartridges and thermally isolated by PTFE foil (see Fig. 1b).

Conductivity measurements.-The specific conductivities of $95 \mathrm{wt} \%$ [2-Sea $\left.{ }^{+}\right][\mathrm{TFO}]$ and $95 \mathrm{wt} \% \mathrm{H}_{3} \mathrm{PO}_{4}$ were determined using the abovedescribed measuring cell in a 2-electrode arrangement, i.e. the $\mathrm{Pt}$ wire as WE and the Pt crucible as CE.

At first, the cell constant was evaluated using a $0.1 \mathrm{M} \mathrm{KCl}$ solution with known specific conductivity. The ohmic resistance of $\mathrm{KCl}$ solutions with volumes of $3.0-4.0 \mathrm{ml}$ (steps of $0.2 \mathrm{ml}$ ) was determined from fits of impedance spectra recorded with $U_{\mathrm{ac}}=50 \mathrm{mV}$ in a frequency range of $1 \mathrm{~Hz}-100 \mathrm{kHz}$ at $T=30^{\circ} \mathrm{C}$. A minimum of $3 \mathrm{ml}$ of electrolyte is necessary to fully wet the protruding Pt wire through the electrolyte. The cell constant was calculated by multiplying the specific conductivity of $0.1 \mathrm{M} \mathrm{KCl}$ with the ohmic resistances. A cell constant of $0.53 \pm 0.01 \mathrm{~cm}^{-1}$ was obtained in the volume range of $3.2-4.0 \mathrm{ml}$. This means that even mass losses of up to $20 \%$ in the subsequent tests with concentrated electrolytes at elevated temperatures would not have a noteworthy effect on the cell constant.

Secondly, the ohmic resistances of both $95 \mathrm{wt} \%\left[2-\mathrm{Sea}^{+}\right]\left[\mathrm{TfO}^{-}\right]$ and $95 \mathrm{wt} \% \mathrm{H}_{3} \mathrm{PO}_{4}$ were determined by continuously heating the cell from $30-130^{\circ} \mathrm{C}$ and simply measuring the impedance at a constant frequency of $1 \mathrm{kHz}$, close to the high-frequency intercept $Z(\varphi \approx 0)$ of the corresponding Nyquist plots with the real axis. This straight-forward procedure is justified, as the maximum deviation of the $Z(\varphi \approx 0)$ values from ohmic resistances obtained from fits of full impedance spectra is only $0.45 \%$. The advantage of such single-frequency experiments is the saving of time and thus a minimization of water loss during the experiment.

Finally, the cell constant was divided by the measured $Z(\varphi \approx 0)$ values to obtain the specific conductivities.

Polarization curves of the oxygen reduction reaction (ORR).- The polarization curves of the ORR were recorded in a quasi-potentiostatic mode with a scan rate of $5 \mathrm{mV} / \mathrm{s}$. The measurements were carried out at temperatures of $30-130^{\circ} \mathrm{C}$ in steps of 20 degrees. Each temperature step took about 20 minutes. The starting potential was $1.25 \mathrm{~V}$ (RHE) and the final potential $0.05 \mathrm{~V}$ (RHE). $1 \mathrm{~h}$ before and during the experiments, the electrolyte $\left(95 \mathrm{wt} \%\left[2-\mathrm{Sea}^{+}\right]\left[\mathrm{TfO}^{-}\right]\right.$or $\left.95 \% \mathrm{H}_{3} \mathrm{PO}_{4}\right)$ was purged with $5 \mathrm{ml} / \mathrm{min}$. $\mathrm{O}_{2}$. This flow rate was derived from a time dependent conductivity measurement with a varying flow rate (2$20 \mathrm{ml} / \mathrm{min}$.) as the best compromise to ensure a sufficient gas supply on the one hand and leading to a very small loss of water on the other. Mass calculations and Karl Fischer titrations revealed that even after applying temperatures up to $130^{\circ} \mathrm{C}$, the composition of both [2-Sea $\left.{ }^{+}\right]\left[\mathrm{TfO}^{-}\right]$and $\mathrm{H}_{3} \mathrm{PO}_{4}$ could be kept within a range of 94.7$95.3 \mathrm{wt} \%$.

Cyclic voltammograms $(C V s)$. - CVs were recorded with a scan rate of $100 \mathrm{mV} / \mathrm{s}$ in a range of $0.05-1.3 \mathrm{~V}$ (RHE) at the same temperatures as described in the last section. The purging conditions were similar to those described for the polarization curves, but $\mathrm{N}_{2}$ was used instead of $\mathrm{O}_{2}$. The CVs were repeated for 30 cycles until a stationary 
voltammogram was obtained. Hydrogen desorption charge densities corrected by double layer charging were calculated from the $30^{\text {th }}$ cycle of each CV. Both the polarization curves and cyclic voltammograms were corrected by the IR drop. Ohmic resistance was calculated by means of impedance measurements.

Thermoanalysis.-Thermogravimetry with differential thermal analysis $(T G A / D T A) .-$ The thermal stability of the $\left[2-\mathrm{Sea}^{+}\right]\left[\mathrm{TfO}^{-}\right]$ was examined using a Perkin Elmer STA 6000 device. Dry pressurized air with a dew point below $-90^{\circ} \mathrm{C}$ was used as the measurement gas and samples with an average initial mass to about $15 \mathrm{mg}$ were placed in an alumina crucible. The analysis was carried out in the temperature range from $23^{\circ} \mathrm{C}$ up to $200^{\circ} \mathrm{C}$ using a $5^{\circ} \mathrm{C} / \mathrm{min}$ heating rate. Due to the strong hygroscopic behavior of the sample, repetitive measurements were performed without removing the sample until identical behavior was achieved in order to obtain data from the water-free samples.

The baseline correction of the gravimetric and thermal signal was performed using an identical measurement program, but with an empty crucible.

Viscosity measurements. - The dynamic viscosity of $95 \mathrm{wt} \%$ $\left[2-\mathrm{Sea}^{+}\right]\left[\mathrm{TfO}^{-}\right]$was measured by means of a Malvern Kinexus Pro rheometer that had been equipped with an $\mathrm{N}_{2}$-flooded active cartridge hood. Using a $1^{\circ} / 25 \mathrm{~mm}$ geometry, the required sample volume in the plate-cone setup was determined to be less than $0.1 \mathrm{ml}$. The temperature was kept constant $( \pm 0.01 \mathrm{~K})$ in the range from 30 to $100^{\circ} \mathrm{C}$. The limit of $100^{\circ} \mathrm{C}$ was chosen to prevent a contamination of the viscometer by traces of triflic acid. For each temperature, two consecutive measurements with different shear rates of 100 and $1000 \mathrm{~s}^{-1}$ were performed. Because the viscosity of $95 \mathrm{wt} \%\left[2-\mathrm{Sea}^{+}\right]\left[\mathrm{TfO}^{-}\right]$is little depending on the shear rate (average deviation $\approx 7 \%$ ), an average viscosity of the measurements with different shear rates was calculated for each temperature.

\section{Results and Discussion}

Thermoanalysis. - The thermal stability of the water-free $\left[2-\mathrm{Sea}^{+}\right]\left[\mathrm{TfO}^{-}\right]$is presented in Figure 2 . Due to its strong hygroscopic behavior, comparable measurements of the hydrated state are hardly feasible. Distinctive features like mass loss rate for a specific temperature are different or phase transitions appear at different temperatures depending on the initial state of the sample. Small changes in the water content have a significant influence on the thermal behavior. However, the dehydrated state also shows reproducible behavior (see Fig. 2).

Several cycles were needed to completely remove water residuals from the compound. The water-free compound featured a constant

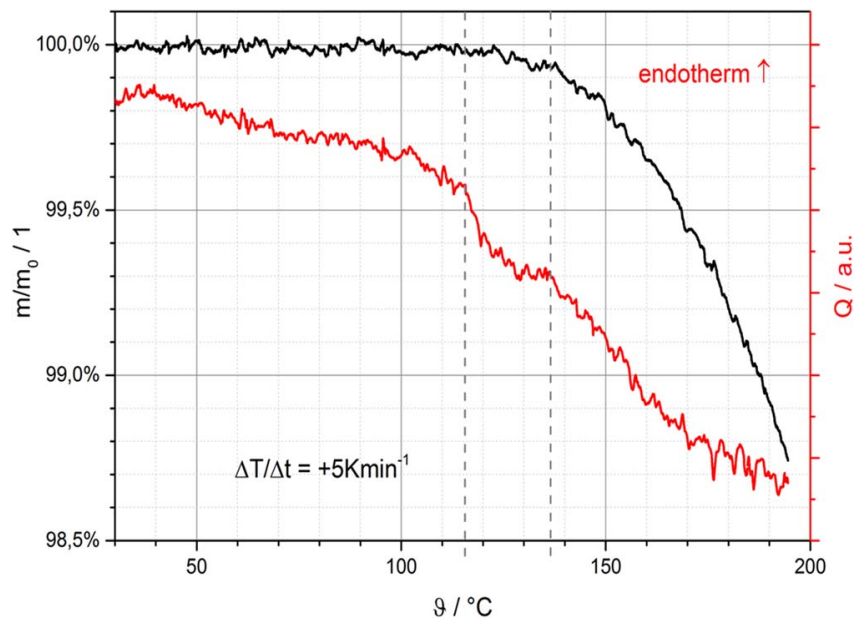

Figure 2. Thermoanalysis (TGA/DTA) of the dehydrated $\left[2-\mathrm{Sea}^{+}\right]\left[\mathrm{TfO}^{-}\right]$, $(-)$ TGA, (- $)$ DTA.

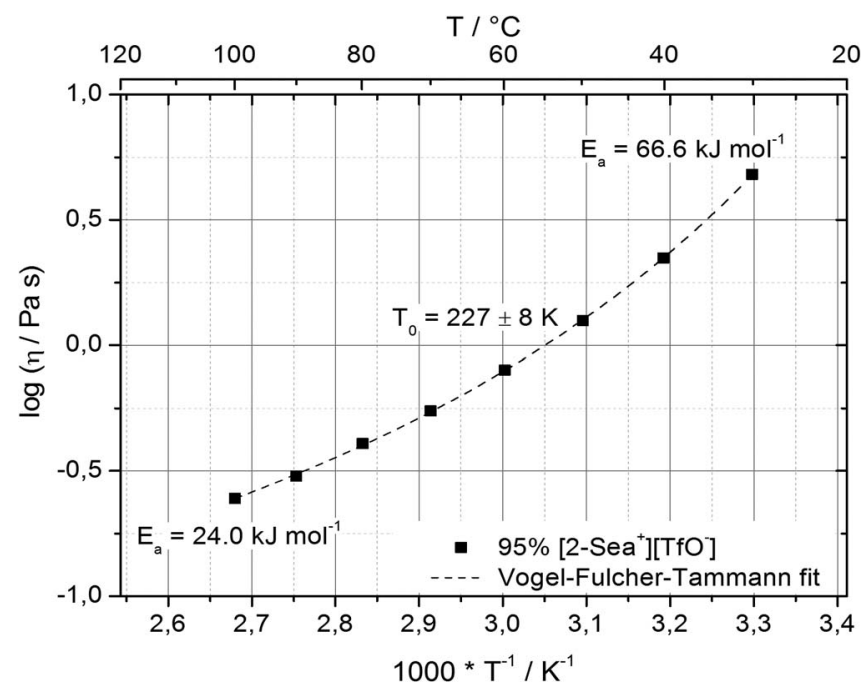

Figure 3. Arrhenius plot of the dynamic viscosity of $95 \mathrm{wt} \%\left[2-\mathrm{Sea}^{+}\right]\left[\mathrm{TfO}^{-}\right]$ ), VFT fits (- - )

mass and no distinctive features were found in the DTA signal for temperatures below $110^{\circ} \mathrm{C}$. At about $115^{\circ} \mathrm{C}$, a slightly exothermal shift in the DTA signal appeared, while the mass seemed to be stable. This feature was also accompanied by a change in the mass loss rate during the dehydration cycles (not shown here). It consistently appeared at the same temperature, independent of the degree of dehydration. This suggests a phase transition of the IL related to water molecule binding, but without further investigation, its origin remains unclear. At about $140^{\circ} \mathrm{C}$, mass loss becomes significant and a change in the trend of the DTA signal also appears. This could indicate a decomposition of $\left[2-\mathrm{Sea}^{+}\right]\left[\mathrm{TfO}^{-}\right]$above $140^{\circ} \mathrm{C}$ by evaporation of TFMSA, since the decomposition temperature of pure taurine is about $300^{\circ} \mathrm{C}$ and the boiling point of pure TFMSA is reported to be about $162^{\circ} \mathrm{C}$. Additional measurements up to $1000^{\circ} \mathrm{C}$ (not shown here) support this. These findings, however, indicate that $140^{\circ} \mathrm{C}$ is the upper temperature limit for the usage of $\left[2-\mathrm{Sea}^{+}\right]\left[\mathrm{TfO}^{-}\right]$.

Viscosity measurements. - The Arrhenius plot of the dynamic viscosity of $95 \mathrm{wt} \%\left[2-\mathrm{Sea}^{+}\right]\left[\mathrm{TfO}^{-}\right]$in a temperature range of $30-100^{\circ} \mathrm{C}$ is shown in Fig. 3. This plot is obviously non-linear and can be well approximated by the Vogel-Fulcher-Tammann-(VFT) equation for dynamic viscosity:

$$
\eta=\eta_{0} e^{\frac{B \eta}{T-T_{0}}}
$$

Here, $\eta_{0}$ is the pre-exponential factor of viscous flow, $B_{\eta}$ is the pseudo activation energy of viscous flow and $T_{0}$ is a critical temperature, where the free volume between the particles is assumed to be zero. The VFT fit reveals a critical temperature of $227 \pm 8 \mathrm{~K}$, which is about $50 \mathrm{~K}$ higher than the value of $170 \mathrm{~K}$ reported for $95 \mathrm{wt} \%$ $\mathrm{H}_{3} \mathrm{PO}_{4}{ }^{59}$ This result indicates stronger intramolecular forces in the case of $\left[2-\mathrm{Sea}^{+}\right]\left[\mathrm{TfO}^{-}\right]$, which is also supported by the high viscosity of $95 \mathrm{wt} \%\left[2-\mathrm{Sea}^{+}\right]\left[\mathrm{TfO}^{-}\right]$in the range of $250-4800 \mathrm{mPa}$ $\mathrm{s}\left(30-100^{\circ} \mathrm{C}\right){ }^{\mathrm{e}}$ These values are $12-53$ times larger than those of $95 \mathrm{wt} \% \mathrm{H}_{3} \mathrm{PO}_{4}{ }^{59}$

The apparent activation energy $E_{\mathrm{a}}$ of the viscous flow, assuming an Arrhenius-like behavior, can be calculated as follows:

$$
E_{a}=R\left(\frac{T}{T-T_{0}}\right)^{2} B_{\eta}
$$

As shown in Fig. 3, the apparent activation energy $E_{\mathrm{a}}$ decreases from $\approx 67 \mathrm{~kJ} \mathrm{~mol}^{-1}\left(30^{\circ} \mathrm{C}\right)$ to $24 \mathrm{~kJ} \mathrm{~mol}^{-1}\left(100^{\circ} \mathrm{C}\right)$. 


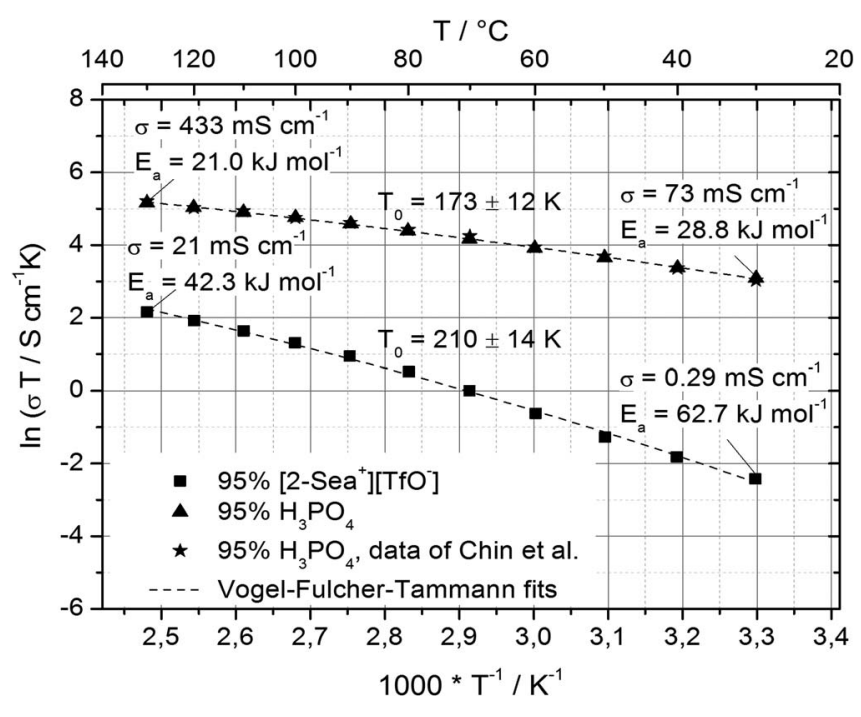

Figure 4. Arrhenius plots of the specific conductivities of $95 \mathrm{wt} \%$ $\left[2-\mathrm{Sea}^{+}\right]\left[\mathrm{TfO}^{-}\right](\mathbf{\square})$ and $95 \mathrm{wt} \% \mathrm{H}_{3} \mathrm{PO}_{4}(\boldsymbol{\Lambda}$ : measured data, $\star$ : data taken from Chin et al. $\left.{ }^{60}\right)$, VFT fits (- - ).

Conductivity measurements.- Fig. 4 shows the Arrhenius plots of the total specific conductivity $\sigma$ of $95 \mathrm{wt} \%\left[2-\mathrm{Sea}^{+}\right]\left[\mathrm{TfO}^{-}\right]$and $95 \mathrm{wt} \% \mathrm{H}_{3} \mathrm{PO}_{4}$ in a temperature range of $30-130^{\circ} \mathrm{C}$. The specific conductivities of $95 \mathrm{wt} \% \mathrm{H}_{3} \mathrm{PO}_{4}$ correspond closely with the literature data taken from Chin et al. ${ }^{60}$ which proves the applicability of the cell design and accuracy of the method. Depending on temperature, the specific conductivity of $95 \mathrm{wt} \%\left[2-\mathrm{Sea}^{+}\right]\left[\mathrm{TfO}^{-}\right]$is $\approx 20$ times $\left(130^{\circ} \mathrm{C}\right)$ to $\approx 250$ times $\left(30^{\circ} \mathrm{C}\right)$ lower than that of $95 \mathrm{wt} \% \mathrm{H}_{3} \mathrm{PO}_{4}$. It should be noted that the conductivity of $\left[2-\mathrm{Sea}^{+}\right]\left[\mathrm{TfO}^{-}\right]$is more influenced by the water content than that of $\mathrm{H}_{3} \mathrm{PO}_{4}$ : if water content is increased from 5 to $15 \mathrm{wt} \%$ (not shown here), the specific conductivity increases only by factors of $1.4\left(130^{\circ} \mathrm{C}\right)$ and $1.6\left(30^{\circ} \mathrm{C}\right)$ in the case of $85 \mathrm{wt} \% \mathrm{H}_{3} \mathrm{PO}_{4}$, but by factors of $\approx 5\left(130^{\circ} \mathrm{C}\right)$ and $\approx 140\left(30^{\circ} \mathrm{C}\right)$ for $85 \mathrm{wt} \%\left[2-\mathrm{Sea}^{+}\right]\left[\mathrm{TfO}^{-}\right]$. As a result, the ratio of specific conductiv-

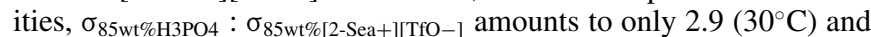
$4.2\left(130^{\circ} \mathrm{C}\right)$, respectively. These results indicate that in the (water-free) $100 \mathrm{wt} \%\left[2-\mathrm{Sea}^{+}\right]\left[\mathrm{TfO}^{-}\right]$, the charge transport mainly takes place via a comparably slow vehicle mechanism (see also Walden plots). In the case of $100 \mathrm{wt} \% \mathrm{H}_{3} \mathrm{PO}_{4}$, the formation of mobile charge carriers by a pronounced autoprotolysis also enables an additional cooperative proton transfer mechanism, which is usually faster than any vehicular mechanism. When adding the amphoter water to both electrolytes, the cooperative proton transfer via $\mathrm{H}_{2} \mathrm{O}$ molecules will take over the total charge transfer. The cooperative proton transfer via $\mathrm{H}_{2} \mathrm{O}$ molecules is faster than via $\mathrm{H}_{3} \mathrm{PO}_{4}$, resulting in a levelling of the differences between $\mathrm{H}_{3} \mathrm{PO}_{4}$ and $\left[2-\mathrm{Sea}^{+}\right]\left[\mathrm{TfO}^{-}\right]$.

Similar to the viscosity data, the data of the specific conductivity also features VTF-behavior. It can be described by the following equation:

$$
\sigma=\sigma_{0} * e^{\frac{B_{\sigma}}{T-T_{0}}}
$$

where $\sigma_{0}$ is the pre-exponential factor of specific conductivity, $B_{\sigma}$ is the pseudo activation energy of ion transport and $T_{0}$ is the critical temperature for the conductivity. The $T_{0}$ value of $95 \mathrm{wt} \%\left[2-\mathrm{Sea}^{+}\right]\left[\mathrm{TfO}^{-}\right]$, $210 \pm 14 \mathrm{~K}$ is close to the critical temperature of viscosity, $227 \pm$ $8 \mathrm{~K}$ (see Viscosity measurements section). This is comparable to the findings for $95 \mathrm{wt} \% \mathrm{H}_{3} \mathrm{PO}_{4}$ with a critical temperature $T_{0}$ for the conductivity of $173 \pm 12 \mathrm{~K}$, which is also almost identical to the critical temperature for a dynamic viscosity of $170 \mathrm{~K}$ (see Viscosity measurements section). The temperature-dependent apparent activation energy of the ionic transport, $E_{a}$, can be calculated as follows:

$$
E_{a}=R T+R\left(\frac{T}{T-T_{0}}\right)^{2} B_{\sigma}
$$

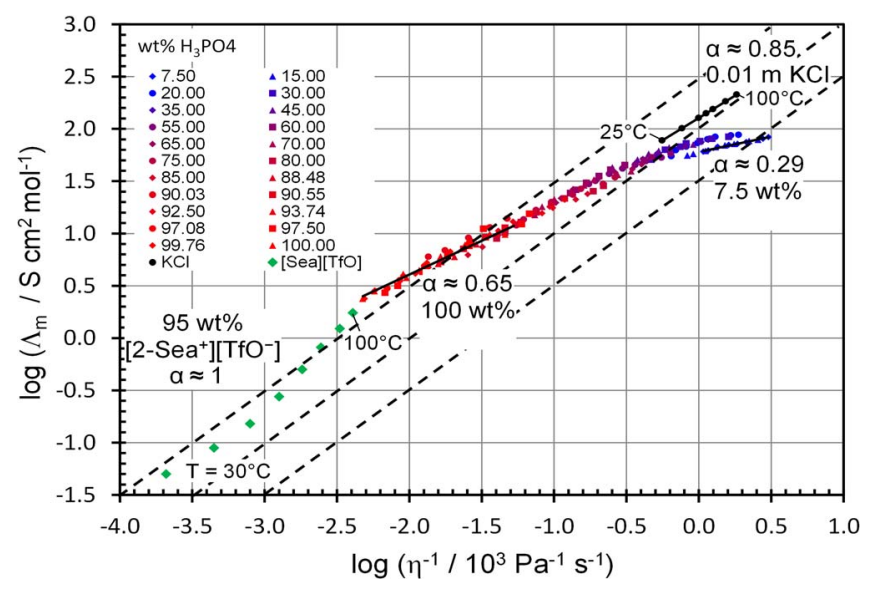

Figure 5. Walden plots of $95 \mathrm{wt} \%\left[2-\mathrm{Sea}^{+}\right]\left[\mathrm{TfO}^{-}\right]\left(\mathrm{T}=30-100^{\circ} \mathrm{C}\right), 7.5-$ $100 \mathrm{wt} \% \mathrm{H}_{3} \mathrm{PO}_{4}$ and $0.01 \mathrm{M} \mathrm{KCl}$ (both $\mathrm{T}=25-100^{\circ}$ ); $\left[2-\mathrm{Sea}^{+}\right]\left[\mathrm{TfO}^{-}\right]$: dynamic viscosity data taken from Fig. 3, molar conductivity calculated by dividing the specific conductivity (taken from Fig. 4) by the molar concentration $\left(5.75 * 10^{-3} \mathrm{~mol} \mathrm{~cm}^{-3}\right) ; \mathrm{H}_{3} \mathrm{PO}_{4}$ and $\mathrm{KCl}$ : data taken from Ref. 59.

The $E_{a}$ values of $\left[2-\mathrm{Sea}^{+}\right]\left[\mathrm{TfO}^{-}\right]\left(\approx 42-63 \mathrm{~kJ} \mathrm{~mol}^{-1}\right)$ are approximately twice those of $\mathrm{H}_{3} \mathrm{PO}_{4}\left(\approx 21-29 \mathrm{~kJ} \mathrm{~mol}^{-1}\right)$. The latter values are close to the data reported in the literature $\left(\approx 16-27 \mathrm{~kJ} \mathrm{~mol}^{-1}\right.$, see Ref. 59). At least for moderate temperatures, pseudo activation energies, as well as the apparent activation energies of ion transport and viscous flow in $95 \mathrm{wt} \%\left[2-\mathrm{Sea}^{+}\right]\left[\mathrm{TfO}^{-}\right]$, are roughly equal. Together with the similar $T_{0}$ values, this suggests a strong coupling of ion transport and viscous flow.

Walden plot.-In order to determine the degree of coupling between proton conductivity and viscous flow, the total molar conductivity $\Lambda$ was plotted against the reciprocal viscosity $1 / \eta$ in a double-logarithmic scale ("Walden plot"). The slope of this plot, $\alpha$, is equal to the ratio of the (pseudo) activation energies $B_{\sigma} / B_{\eta}{ }^{59}$ :

$$
\Lambda \eta=\text { const } . \quad \text { and } \quad \alpha=\frac{B_{\sigma}}{B_{\eta}}
$$

In the case of only vehicular transport, proton conductivity and viscous flow is strictly coupled, i.e. $B_{\sigma} \approx B_{\eta}$. This will result in a slope, $\alpha$, of about 1 . The (pseudo) activation energy for the proton conduction will decrease in comparison to viscous flow due to additional or exclusive cooperative proton transport, i.e. $B_{\sigma}<B_{\eta}$. With an increasing degree of decoupling between proton transport and viscous flow, the slope is decreasing, i.e. $\alpha \leq 1$.

Fig. 5 compares Walden plots of $95 \mathrm{wt} \%\left[2-\mathrm{Sea}^{+}\right]\left[\mathrm{TfO}^{-}\right](T=30-$ $\left.100^{\circ} \mathrm{C}\right)$ with those of $7.5-100 \mathrm{wt} \% \mathrm{H}_{3} \mathrm{PO}_{4}$ and $0.01 \mathrm{M} \mathrm{KCl}(T=25-$ $\left.100^{\circ}\right)$. In the case of $\left[2-\mathrm{Sea}^{+}\right]\left[\mathrm{TfO}^{-}\right]$, the slope $\alpha$ of the Walden plot is close to 1 , which supports the assumption of a strong coupling of ion transport and viscous flow. This suggests a predominantly vehicular ion transport mechanism in $\left[2-\mathrm{Sea}^{+}\right]\left[\mathrm{TfO}^{-}\right]$, as is the case for aqueous $\mathrm{KCl}$ solutions.

In contrast, the low $\alpha$ value of 0.65 for high concentrations of $\mathrm{H}_{3} \mathrm{PO}_{4}$ indicates a considerable share of cooperative proton transport, which is independent from viscous motion. ${ }^{59}$ The assumption of different transport mechanisms is in accordance with the significantly higher apparent activation energies of ion transport in $\left[2-\mathrm{Sea}^{+}\right]\left[\mathrm{TfO}^{-}\right]$ and the much stronger dependence of the specific conductivity of [2$\left.\mathrm{Sea}^{+}\right]\left[\mathrm{TfO}^{-}\right]$on the addition of water.

Cyclic voltammetry.- Cyclic voltammograms of $\mathrm{Pt}$ in $95 \mathrm{wt} \%$ $\left[2-\mathrm{Sea}^{+}\right]\left[\mathrm{TfO}^{-}\right]$and $95 \mathrm{wt} \% \mathrm{H}_{3} \mathrm{PO}_{4}$ were recorded in a temperature range of $30-130^{\circ} \mathrm{C}$ with a scan rate of $100 \mathrm{mV} / \mathrm{s}$ (see Figs. 6a and 6b). After 5-10 cycles, temporally stable CVs were obtained, revealing the electrochemical stability of both electrolytes. From the $30 \mathrm{CVs}$ recorded for each measurement, the last cycle was always represented. For both $\left[2-\mathrm{Sea}^{+}\right]\left[\mathrm{TfO}^{-}\right]$and $\mathrm{H}_{3} \mathrm{PO}_{4}$, the $\mathrm{PtO}$ reduction potential 

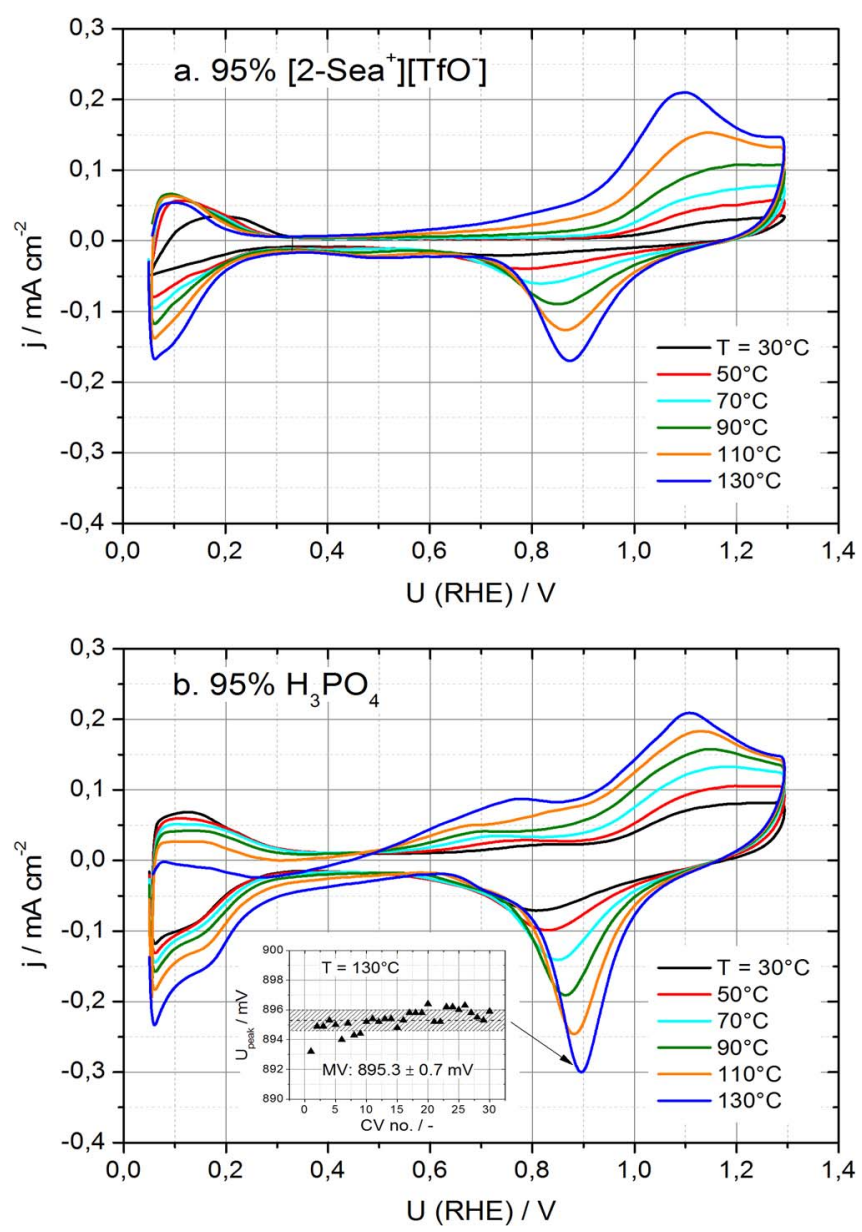

Figure 6. Cyclic voltammograms of $\mathrm{Pt}$ in $95 \mathrm{wt} \%\left[2-\mathrm{Sea}^{+}\right]\left[\mathrm{TfO}^{-}\right]$(a) and $95 \mathrm{wt} \% \mathrm{H}_{3} \mathrm{PO}_{4}$ (b); always the last cycle of $30 \mathrm{CVs}$ represented; $\mathrm{d} U / \mathrm{d} t=100$ $\mathrm{mVs}^{-1}, T=30-130^{\circ} \mathrm{C}$; inset picture in b. shows the reduction potential of $\mathrm{PtO}$ vs. cycle No. for $\mathrm{T}=130^{\circ} \mathrm{C}$.

increases by about $100 \mathrm{mV}$ if the temperature is raised from 30 to $130^{\circ} \mathrm{C}$. In contrast, no drift is caused by operation time, proving the time stability of the reference electrode. This is demonstrated with the inset picture in Fig. 6b, where the reduction potential of $\mathrm{PtO}$ does not change with the cycle number. The following three sections of the CVs can be distinguished: 1) $U<0.4 \mathrm{~V}$ Hydrogen adsorption/desorption; 2) $0.4 \mathrm{~V}<U<0.6 \mathrm{~V}$ : double layer region; and 3) $U>0.7-0.9 \mathrm{~V}$ : $\mathrm{Pt}$ oxidation/PtO reduction. Despite the similarity between the CVs obtained with $95 \mathrm{wt} \%\left[2-\mathrm{Sea}^{+}\right]\left[\mathrm{TfO}^{-}\right]$and $95 \mathrm{wt} \% \mathrm{H}_{3} \mathrm{PO}_{4}$, somereproducible-differences are observed: i) a second oxidation peak is observed for $\mathrm{H}_{3} \mathrm{PO}_{4}$ in the potential range of $0.6-0.8 \mathrm{~V}$; ii) the $\mathrm{PtO}$ reduction peak for $\left[2-\mathrm{Sea}^{+}\right]\left[\mathrm{TfO}^{-}\right]$is comparatively small; iii) slightly distorted $\mathrm{CVs}$ with a current axis sloped upwards are obtained with $\mathrm{H}_{3} \mathrm{PO}_{4}$ at temperatures $\geq 110^{\circ} \mathrm{C}$ in the potential range $<0.5 \mathrm{~V}$, (v) for $\left[2-\mathrm{Sea}^{+}\right]\left[\mathrm{TfO}^{-}\right]$, the onset potential of Pt-OH formation decreases with rising temperature. These features can be analyzed as follows:

(i) According to Sugishima et al., ${ }^{61}$ the additional oxidation peak can be attributed to the oxidation of an impurity-phosphorous acid:

$$
\mathrm{H}_{3} \mathrm{PO}_{3}+\mathrm{H}_{2} \mathrm{O} \rightarrow \mathrm{H}_{3} \mathrm{PO}_{4}+2 \mathrm{H}^{+}+2 \mathrm{e}^{-}
$$

Phosphorous acid can be present as an intrinsic impurity in phosphoric acid, but can also be formed in the hydrogen adsorption region via the reverse reaction in Eq. $12 .{ }^{61}$ Sugishima et al. demonstrate that a clearly visible second oxidation peak is observed with a phosphoric acid of "reagent grade" quality. At temperatures above $100^{\circ} \mathrm{C}$, a small peak is also observed using purified phosphoric acid. ${ }^{61}$ As expected, the peak size obtained with "Suprapur" phosphoric acid used in this work (impurities $<3.5 \mathrm{ppm}$ ) is closer to purified phosphoric acid. Sugishima et al.'s findings reveal that even small amounts of impurities (like $\mathrm{H}_{3} \mathrm{PO}_{3}$ ), which may be negligible if working with highly diluted aqueous solutions, can severely affect electrochemical processes if using highly concentrated solutions. Moreover, the maximum current of the second oxidation peak increases with temperature (see Fig. $6 \mathrm{~b}$ and Sugishima et al. ${ }^{61}$ ), i.e., it may be invisible at low temperatures.

(ii) Generally, the charge of the $\mathrm{PtO}$ formation peak is always higher than that of the PtO reduction peak, because the oxidation current not only involves oxide formation, but also faradaic processes like oxygen formation. ${ }^{62}$ The reduction of oxide to hydrogen peroxide, which is also suggested in the literature, ${ }^{63}$ has not been confirmed ${ }^{62}$ but cannot be completely excluded. In this view, the smaller reduction peak in the presence of $\left[2-\mathrm{Sea}^{+}\right]\left[\mathrm{TfO}^{-}\right]$could either be due to the formation of a thinner oxide layer or only a partial reduction of PtO involving the formation of $\mathrm{H}_{2} \mathrm{O}_{2}$. However, based on the work performed so far, no definite conclusion can be drawn. Likewise, the higher reduction charge of $\mathrm{PtO}$ reduction in the presence of $\mathrm{H}_{3} \mathrm{PO}_{4}$ cannot be attributed to the reduction of $\mathrm{H}_{3} \mathrm{PO}_{4}$ to $\mathrm{H}_{3} \mathrm{PO}_{3}$, because this process occurs in the potential range of hydrogen adsorption $^{61}$ (see above).

(iii) Highly distorted CVs with a current axis sloped upwards have been reported by Scharifker et al. ${ }^{7}$ for $\mathrm{Pt}$ microelectrodes in $98 \mathrm{wt} \%$ phosphoric acid. The distortion is explained by ionic leak currents through the glass from the platinum microelectrode to the surrounding solution. Because the surface area of the Pt wire used in our work is about 4-5 orders of magnitude larger than the area of Scharifker's microelectrode, ionic leak currents due to a gap between the Pt wire and the glass tube can only cause moderate distortions. However, an inspection of the working electrode did not reveal the presence of liquid electrolyte in the center of the glass tube. A plausible alternative explanation is an additional cathodic current caused by the reverse reaction in Eq. 12, which increases with decreasing potential. According to Sugishima et al., the electrochemical formation of phosphorous acid impurities (reverse reaction in Eq. 12) is enhanced at elevated temperatures. This may also explain why the distortion effect only (and reproducibly) appears with phosphoric acid at elevated temperatures and in the potential range below $0.5 \mathrm{~V}$.

(iv) At moderate temperatures (i.e., $\leq 70^{\circ} \mathrm{C}$ ), the onset potential of $\mathrm{Pt}-\mathrm{OH}$ formation in the presence of $95 \mathrm{wt} \%\left[2-\mathrm{Sea}^{+}\right]\left[\mathrm{TfO}^{-}\right]$ is $\approx 0.95 \mathrm{~V}$. This value is about $150 \mathrm{mV}$ higher than the onset potential reported for diluted perchloric acid ${ }^{3}\left(\mathrm{ClO}_{4}{ }^{-}\right.$is not specifically adsorbed on the Pt surface). An even higher potential shift has been reported for $95 \mathrm{wt} \%$ phosphoric acid compared to diluted phosphoric acid and is attributed to both a blocking effect caused by the specific adsorption of phosphate ions and a decrease of water activity with increasing acid concentration. ${ }^{5}$ In the case of $\left[2-\mathrm{Sea}^{+}\right]\left[\mathrm{TfO}^{-}\right]$, the adsorption of $\left[\mathrm{TfO}^{-}\right]$anions-and presumably also $\left[2-\mathrm{Sea}^{+}\right]$cations-may be responsible for the potential shift observed. Thus, a decrease in the onset potential with rising temperature, as observed in Fig. 6a, would correspond to a decrease in $\left[\mathrm{TfO}^{-}\right] /\left[2-\mathrm{Sea}^{+}\right]$ coverage and a growth in $\mathrm{H}_{2} \mathrm{O}$ coverage on the Pt surface. This assumption is consistent with the substantial increase in the oxidation current at $U<0.95 \mathrm{~V}$ and $T \geq 90^{\circ} \mathrm{C}$ (see Fig. 6a).

Hydrogen desorption charges.-Fig. 7 shows the hydrogen desorption charges, $Q_{H, d e s}$ of $95 \mathrm{wt} \% \mathrm{H}_{3} \mathrm{PO}_{4}$ and $95 \mathrm{wt} \%\left[2-\mathrm{Sea}^{+}\right]\left[\mathrm{TfO}^{-}\right]$, corrected by double layer charging. The measured $Q_{H \text {,des }}$ values amount to only $\approx 20-40 \%$ of the value of smooth polycrystalline Pt electrodes $\left(210 \mu \mathrm{C} / \mathrm{cm}^{2}\right){ }^{51}$ This indicates strong ion adsorption. In the case of $\mathrm{H}_{3} \mathrm{PO}_{4}$, the hydrogen desorption charge $Q_{H, d e s}$ decreases over the whole temperature range, and more steeply at temperatures 


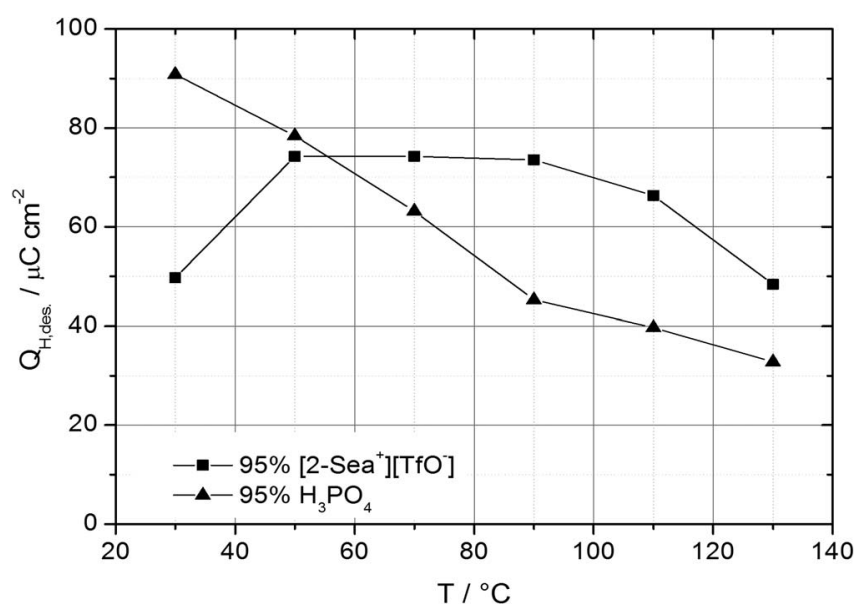

Figure 7. Hydrogen desorption charge densities vs. temperature for $95 \mathrm{wt} \%$ $\left[2-\mathrm{Sea}^{+}\right]\left[\mathrm{TfO}^{-}\right](\mathbf{\square})$ and $95 \mathrm{wt} \% \mathrm{H}_{3} \mathrm{PO}_{4}(\boldsymbol{\Lambda})$ determined from Fig. 6; values corrected by double layer charging.

below $90^{\circ} \mathrm{C}$. This decrease can be explained by the increased formation of phosphorous acid, which interacts even more strongly with a Pt surface than phosphoric acid species.

$\left[2-\mathrm{Sea}^{+}\right]\left[\mathrm{TfO}^{-}\right]$shows a flat maximum of $Q_{H, d e s}$ of $\approx 74 \mu \mathrm{C} \mathrm{cm}^{-2}$. This means that the fraction of the Pt surface, freely accessible for oxygen, has a maximum in the temperature range between $50-90^{\circ} \mathrm{C}$. As suggested above, the competing effects of decreasing $\left[\mathrm{TfO}^{-}\right] /[2-$ $\mathrm{Sea}^{+}$] coverage and an increase in $\mathrm{H}_{2} \mathrm{O} /-\mathrm{OH}$ coverage could explain such a maximum. Although poisoning effects by sulfur compounds for instance cannot be excluded, such an explanation seems to be rather unlikely, since the effect of sulfur-containing compounds has been reported to decrease with rising temperature. ${ }^{64}$ However, despite the decreasing hydrogen desorption charge at elevated temperatures, $Q_{H, d e s}\left(\left[2-\mathrm{Sea}^{+}\right]\left[\mathrm{TfO}^{-}\right]\right)$is up to $40 \%$ higher than $Q_{H, d e s}\left(\mathrm{H}_{3} \mathrm{PO}_{4}\right)$, indicating a less poisoning effect by $\left[2-\mathrm{Sea}^{+}\right]\left[\mathrm{TfO}^{-}\right]$.

Differential double layer capacitance.-A comprehensive investigation of the differential double layer capacitance by means of EIS is beyond the scope of the present study, but will be part of future work. To get a first insight, $\mathrm{C}_{\mathrm{D}}$ was calculated from the charging current density, $j_{d}$, in the double layer region $(U \approx 0.5 \mathrm{~V})$ according to the following equation:

$$
\mathrm{C}_{\mathrm{D}}=\frac{\mathrm{j}_{\mathrm{D}}}{\left(\frac{\mathrm{dU}}{\mathrm{dt}}\right)}
$$

For both electrolytes, $C_{D}$ tends to increase with temperature (see Fig. 8). This behavior is contradictory to the model of Gouy-ChapmanStern, developed for diluted electrolytes, ${ }^{65}$ which predicts a decrease of double layer capacitance with increasing temperature. It is, however, a common behavior of ionic liquids ${ }^{66}$ and, in the case of concentrated phosphoric acid under HT-PEFC operating conditions, has also been observed in a work of ours that was published three years ago. ${ }^{67}$ Lockett et al. explain the growth of the differential capacitance with temperature through a thinning of the double layer due to the thermal dissociation of ion associates. ${ }^{66}$ However, in our case it is unlikely to observe such effects because the time constants of dissociation of weakly coordinating ions are much smaller than the time window of the used measuring technique. Further frequency-dependent measurements will reveal if this increase could be due to a superposition of different capacitive processes with different time constants, according to the findings of Drüschler et al. ${ }^{68}$

As can be seen in Fig. 8, the $C_{D}$ values obtained with $\mathrm{H}_{3} \mathrm{PO}_{4}$ are $1.3-2.4$ times higher than those of $\left[2-\mathrm{Sea}^{+}\right]\left[\mathrm{TfO}^{-}\right]$. This can easily be explained by the lower relative permittivity $\varepsilon_{r}$ in the case of the ionic liquid $\left[2-\mathrm{Sea}^{+}\right]\left[\mathrm{TfO}^{-}\right]$. It is well-known that water, with its dipolar molecules, has the high relative permittivity of 78.5 at $25^{\circ} \mathrm{C},{ }^{69}$ which is attributed to the strong interaction of water molecules by $\mathrm{H}$ bonds.

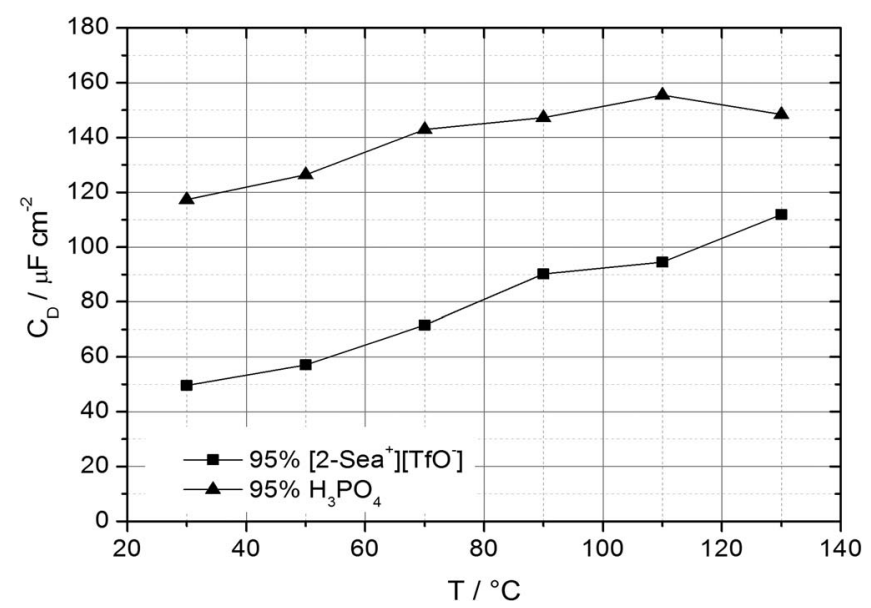

Figure 8. Differential double layer capacitances vs. temperature for $95 \mathrm{wt} \%$ $\left[2-\mathrm{Sea}^{+}\right]\left[\mathrm{TfO}^{-}\right](\mathbf{\square})$ and $95 \mathrm{wt} \% \mathrm{H}_{3} \mathrm{PO}_{4}(\boldsymbol{\Lambda})$ determined from Fig. 6; values calculated from the charging current densities in the double layer region $(0.4 \mathrm{~V}$ $<U<0.6 \mathrm{~V})$.

Comparable strong interactions via $\mathrm{H}$ bonds are present in $100 \mathrm{wt} \%$ phosphoric acid, resulting in a high $\varepsilon_{r}$ value of 61 at $25^{\circ} \mathrm{C},{ }^{70}$ too. The $\left[2-\mathrm{Sea}^{+}\right]$cation contains both a $-\mathrm{SO}_{3} \mathrm{H}$ and $\mathrm{a}-\mathrm{NH}_{3}{ }^{+}$group. Even though the dielectric constant is not yet known, the interaction of [2$\mathrm{Sea}^{+}$] cations by $\mathrm{H}$ bonds seems likely. It suggests that the relative permittivity $\varepsilon_{r}$ of $\left[2-\mathrm{Sea}^{+}\right]\left[\mathrm{TfO}^{-}\right]$is higher than that for imidazoliumbased ionic liquids like $\left[\mathrm{EMIm}^{+}\right]\left[\mathrm{TfO}^{-}\right](15.1)$ and $\left[\mathrm{BMIm}^{+}\right]\left[\mathrm{TfO}^{-}\right]$ (13.2), as reported by Weingärtner. ${ }^{71}$ This assumption is also supported by the observation of Weingärtner that ethylammonium nitrate $\left[\mathrm{EtNH}_{3}{ }^{+}\right]\left[\mathrm{NO}_{3}{ }^{-}\right]$, which is able to form strong hydrogen bonds, shows a significantly higher $\varepsilon_{r}$ value of $26.2 .^{71}$ However, it should be kept in mind that these $\varepsilon_{r}$ values are relative permeabilites of bulk electrolytes. In the electric field of a double layer, the average $\varepsilon_{r}$ values will be much lower because of dielectric saturation. ${ }^{72,73}$

Beneath the relative permittivity, the double layer thickness is the second important parameter. An ionic liquid tends to form ordered structures of associated anions and cations. ${ }^{74}$ Furthermore, both the $\left[2-\mathrm{Sea}^{+}\right]$cation and the $\left[\mathrm{TfO}^{-}\right]$anion have a larger average diameter than the $\mathrm{H}_{2} \mathrm{PO}_{4}{ }^{-}$anion, thus increasing the double layer thickness. It can therefore be assumed that a thicker double layer is formed in the case of $\left[2-\mathrm{Sea}^{+}\right]\left[\mathrm{TfO}^{-}\right]$.

The absolute $C_{D}$ values of both $95 \mathrm{wt} \%\left[2-\mathrm{Sea}^{+}\right]\left[\mathrm{TfO}^{-}\right]$and $\mathrm{H}_{3} \mathrm{PO}_{4}$ are about five to ten times higher than typical values obtained for pure ionic liquids $\left(10 \mu \mathrm{F} / \mathrm{cm}^{2}\right.$ and less $\left.{ }^{66,75}\right)$ and are more similar to those measured with diluted aqueous electrolytes. The results suggest that the double layer properties of the interface $\mathrm{Pt} / 95 \mathrm{wt} \%$ $\left[2-\mathrm{Sea}^{+}\right]\left[\mathrm{TfO}^{-}\right]$or $\mathrm{H}_{3} \mathrm{PO}_{4}$ combine those of $\mathrm{Pt}$ in diluted electrolytes (the absolute value of the capacitance $C_{D}$ ) and in pure electrolytes / ionic liquids (the temperature dependence, the decreasing thickness of double layer). It should be remembered that despite the small amount of water in terms of wt\%, the molar ratios are $1: 1.2$ for $\mathrm{H}_{2} \mathrm{O} /$ [2$\left.\mathrm{Sea}^{+}\right]\left[\mathrm{TfO}^{-}\right]$and $1: 3.5$ for $\mathrm{H}_{2} \mathrm{O} / \mathrm{H}_{3} \mathrm{PO}_{4}$. Thus, especially in the case of $\left[2-\mathrm{Sea}^{+}\right]\left[\mathrm{TfO}^{-}\right]$, water molecules are highly present in the platinum / electrolyte interface and influence the double layer properties. Together with the assumed higher dielectric constant of $\left[2-\mathrm{Sea}^{+}\right]\left[\mathrm{TfO}^{-}\right]$ compared to most other ionic liquids, the high double layer capacitance can be well explained. These findings can be underpinned with preliminary impedance measurements (not shown here).

Polarization measurements. - The quasi-stationary polarization curves of the oxygen reduction reaction (ORR) on $\mathrm{Pt}$ in $95 \mathrm{wt} \%$ $\left[2-\mathrm{Sea}^{+}\right]\left[\mathrm{TfO}^{-}\right]$and $95 \mathrm{wt} \% \mathrm{H}_{3} \mathrm{PO}_{4}$ were recorded in a temperature range of $30-130^{\circ} \mathrm{C}$ with a scan rate of $5 \mathrm{mV} / \mathrm{s}$ in the cathodic sweep direction and an oxygen flow rate of $5 \mathrm{ml} / \mathrm{min}$. Linear $j / U$ curves and the corresponding Tafel plots are shown in Figs. 9a and 9b. The most 

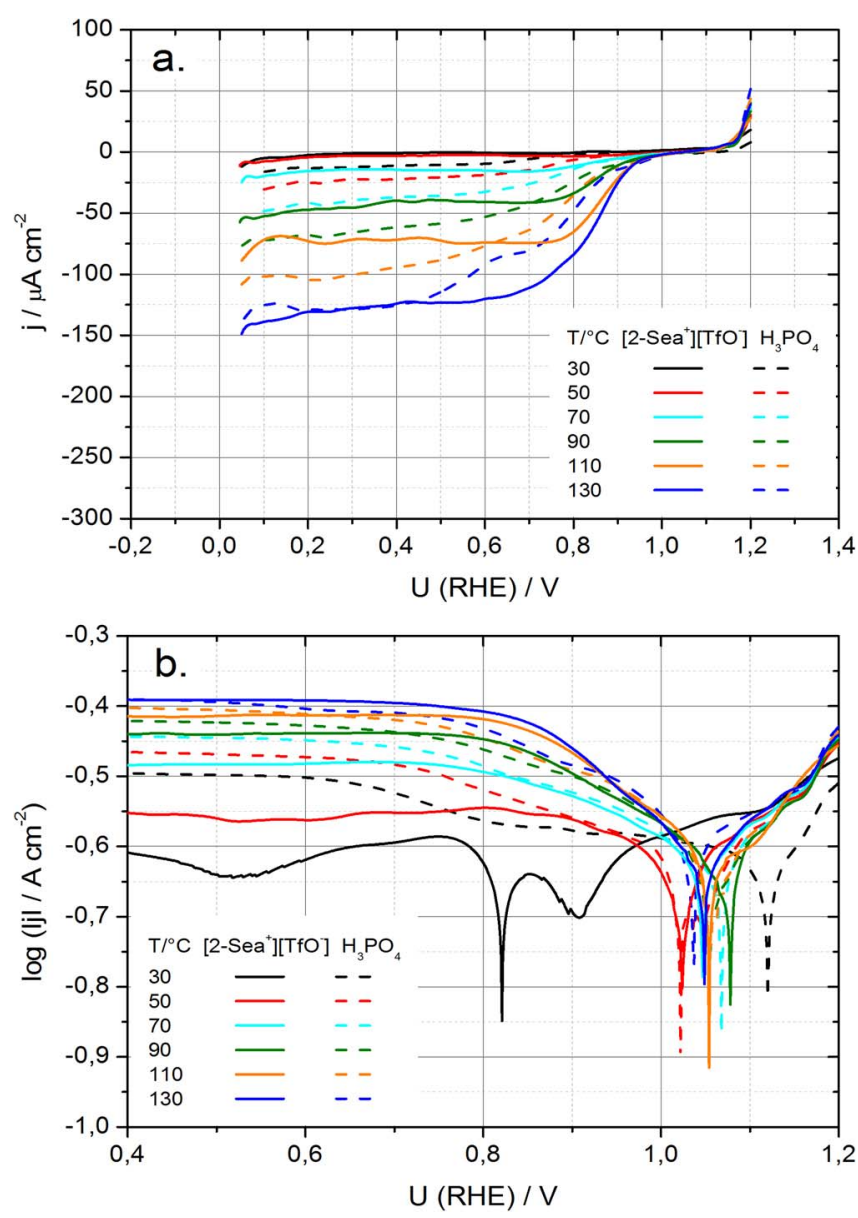

Figure 9. Quasi-stationary polarization curves of ORR on Pt in $95 \mathrm{wt} \%$ [2$\left.\mathrm{Sea}^{+}\right]\left[\mathrm{TfO}^{-}\right]$and $95 \mathrm{wt} \%$. $\mathrm{H}_{3} \mathrm{PO}_{4} ;$ a. linear $j / U$ curves, $b$. Tafel plots; $\mathrm{d} U / \mathrm{d} t$ $=5 \mathrm{mVs}^{-1}, T=30-130^{\circ} \mathrm{C}$; cathodic sweep direction.

important result is the superior performance with $\left[2-\mathrm{Sea}^{+}\right]\left[\mathrm{TfO}^{-}\right]$ compared to $\mathrm{H}_{3} \mathrm{PO}_{4}$ at temperatures $\geq 90^{\circ} \mathrm{C}$ and in the applicationrelevant potential range of $0.7-0.9 \mathrm{~V}$. This is obviously due to a more pronounced increase of ORR current density with rising temperature in the presence of $\left[2-\mathrm{Sea}^{+}\right]\left[\mathrm{TfO}^{-}\right]$.

Except the $30^{\circ} \mathrm{C}$ measurement with $\left[2-\mathrm{Sea}^{+}\right]\left[\mathrm{TfO}^{-}\right]$, the open circuit potentials have stable values within a range of about $100 \mathrm{mV}$ (see Fig. 9b). Because the OCV measurement at $30^{\circ} \mathrm{C}$ shows a poor reproducibility and no evaluable Tafel slope for the ORR, it was not considered further. According to Murthi et al. ${ }^{30}$ and Wroblowa et al., ${ }^{76}$ the OCV is attributed to a mixed potential that is established by ORR kinetics and anodic processes like Pt oxide formation and the oxidation of impurities. Thus, the very small and undefined ORR current of the $30^{\circ} \mathrm{C}$ measurement with $\left[2-\mathrm{Sea}^{+}\right]\left[\mathrm{TfO}^{-}\right]$caused by strong ion adsorption could explain the poor reproducibility of this measurement.

The ratio of the current densities obtained with $\left[2-\mathrm{Sea}^{+}\right]\left[\mathrm{TfO}^{-}\right]$ and $\mathrm{H}_{3} \mathrm{PO}_{4}$ increases with temperature. At $T \geq 70^{\circ} \mathrm{C}$, in an increasing potential range the current density $j\left(\left[2-\mathrm{Sea}^{+}\right]\left[\mathrm{TfO}^{-}\right]\right)$becomes larger than $j\left(\mathrm{H}_{3} \mathrm{PO}_{4}\right)$. For $130^{\circ} \mathrm{C}$, it extends from 0.43 to $0.93 \mathrm{~V}$ (Figs. 9a and $9 \mathrm{~b}$ ). The ORR limiting current shows a similar behavior: At low temperatures, the ORR limiting current of $\left[2-\mathrm{Sea}^{+}\right]\left[\mathrm{TfO}^{-}\right]$is about one order of magnitude smaller than $j_{\text {lim }}\left(\mathrm{H}_{3} \mathrm{PO}_{4}\right)$. With rising temperature, $j_{\lim }\left(\left[2-\mathrm{Sea}^{+}\right]\left[\mathrm{TfO}^{-}\right]\right)$increases more rapidly than $j_{\text {lim }}$ $\left(\mathrm{H}_{3} \mathrm{PO}_{4}\right)$ and reaches the same value at $130^{\circ} \mathrm{C}$ (Fig. 9a). The limiting current is primarily determined by the product of oxygen diffusivity, $D_{\mathrm{O} 2}$, and oxygen solubility, $c_{\mathrm{O} 2}$, in the used electrolytes. Whereas sufficient diffusivity of oxygen is especially important for HT-PEFC operation under high loads, adequate oxygen solubility is important for the whole current range.
Huang et al. obtained least-squares correlation coefficients $R^{2}$ of $0.5-0.65$ for the linear regression of plots $D_{\mathrm{O} 2} \mathrm{vs} . \eta^{-1}$ for the diffusivity of oxygen in several ionic liquids. ${ }^{77}$ Condemarin and Scovazzo found that the diffusivity of several gases in different ionic liquids scales inversely with the square-root of viscosity and the power of 1-1.3 of the gas solute molar volume. ${ }^{78}$ Hence, the temperature dependence of the limiting currents can, at least in part, be explained by the higher activation energy of the viscosity of $95 \mathrm{wt} \%\left[2-\mathrm{Sea}^{+}\right]\left[\mathrm{TfO}^{-}\right] \mathrm{com}-$ pared to $95 \mathrm{wt} \% \mathrm{H}_{3} \mathrm{PO}_{4}$. Kilaru et al. ${ }^{79}$ investigated the dependence of gas solubility on the viscosities of ionic liquids and found that gas solubility is inversely proportional to the dynamic viscosity (see Eq. 10 in Ref. 79) i.e., the gas solubility is low in electrolytes with high viscosity and vice versa. If the strong decrease of dynamic viscosity (see Viscosity measurements section) leads to a corresponding increase of oxygen solubility, this could be one of the reasons for the strong increase of current with increasing temperature.

According to Scharifker et al., concentrated phosphoric acid (98 wt\%) shows the anomalous behavior of oxygen solubility. For $T<97^{\circ} \mathrm{C}$, solubility increases with temperature, corresponding to a positive heat of solution, but at $T>97^{\circ} \mathrm{C}$, oxygen solubility is constant, which indicates zero heating of the solution. ${ }^{7}$ As shown by Klinedinst et al., this anomaly is a special phenomenon of highly concentrated phosphoric acids $\geq 96 \mathrm{wt} \%$, where both the enthalpy and entropy terms for oxygen solubility become very small. ${ }^{80}$ Scharifker et al. has explained this anomaly with a change in the structure of $98 \mathrm{wt} \%$ phosphoric acid when exceeding $97^{\circ} \mathrm{C}$ caused by a shift of the equilibrium:

$$
\mathrm{nH}_{3} \mathrm{PO}_{4} \leftrightarrow \mathrm{H}_{\mathrm{n}+2} \mathrm{P}_{\mathrm{n}} \mathrm{O}_{3 \mathrm{n}+1}+(\mathrm{n}-1) \mathrm{H}_{2} \mathrm{O}
$$

toward pyrophosphoric acid and higher polyphosphoric acids with a more netted structure.

Tafel parameters and the rate-determining step.-The dominating overall reaction of oxygen reduction on $\mathrm{Pt}$ in acidic solutions is a direct 4-electron mechanism:

$$
\mathrm{O}_{2}+4 \mathrm{H}^{+}+4 \mathrm{e}^{-} \rightarrow 2 \mathrm{H}_{2} \mathrm{O}
$$

The predominance of this mechanism has also been confirmed for $85 \mathrm{wt} \%$ phosphoric acid ${ }^{81}$ and protic ionic liquids like $\left[\right.$ dema $\left.^{+}\right]\left[\mathrm{TfO}^{-}\right] .^{82}$ Only in the case of a significant addition of impurities, e.g. $10^{-3} \mathrm{M} \mathrm{H}_{3} \mathrm{PO}_{3}$, does the oxygen reduction mainly proceed via an indirect 2-electron mechanism with hydrogen peroxide as product. ${ }^{81}$ Generally, the ORR is complex and proceeds via several single steps involving adsorbed intermediates like $\mathrm{O}_{2, \text { ad }}{ }^{\bullet-}$ (superoxide radical), $\mathrm{OOH}_{\mathrm{ad}}{ }^{\bullet}$ (hydroperoxyl radical), $\mathrm{OH}_{\mathrm{ad}}$ and $\mathrm{O}_{\mathrm{ad}}$. Although the nature of the ORR intermediates has not been unequivocally clarified, the first reduction step involving $\mathrm{O}_{2, \mathrm{ad}}{ }^{\bullet-}$ and $\mathrm{OOH}_{\mathrm{ad}} \bullet$ has been widely accepted as the rate-determining step (rds). ${ }^{83-86}$ The same rds has been proposed for PILs ${ }^{87}$ and $\mathrm{H}_{3} \mathrm{PO}_{4} / \mathrm{PBI}{ }^{12}$ It is assumed that the adsorbed oxygen molecules produce $\mathrm{O}_{2, \mathrm{ad}}{ }^{\bullet-}$ that are subsequently protonated by the formation of $\mathrm{OOH}_{\mathrm{ad}} \cdot 87$ Because of the water content of the electrolytes used here, the situation is even more complex, as both $\mathrm{H}_{3} \mathrm{O}^{+}$and $\mathrm{BH}^{+}$(see Eq. 2b) can serve as the proton source. Hence, the rate-determining step can be written as:

$$
\begin{gathered}
\mathrm{O}_{2, \text { ad }}+\mathrm{e}^{-} \stackrel{\text { rds }}{\longrightarrow} \mathrm{O}_{2, \text { ad }}^{\bullet-} \\
\text { followed by } \quad \mathrm{O}_{2, \text { ad }}^{\bullet-}+\mathrm{H}_{3} \mathrm{O}^{+} \rightarrow \mathrm{OOH}_{\text {ad }}^{\bullet}+\mathrm{H}_{2} \mathrm{O} \\
\text { and/or } \quad \mathrm{O}_{2, \text { ad }}^{\bullet-}+\mathrm{BH}^{+} \rightarrow \mathrm{OOH}_{\text {ad }}^{\bullet}+\mathrm{B}
\end{gathered}
$$

To evaluate the kinetic parameters of the ORR, Tafel plots have to be corrected for mass transport using the following equation: ${ }^{88}$

$$
\log j_{\mathrm{K}}=\log \left(\frac{\mathrm{j}_{\mathrm{L}} \times \mathrm{j}}{\mathrm{j}_{\mathrm{L}}-\mathrm{j}}\right)=\log \mathrm{j}_{0}-\frac{\mathrm{U}}{\mathrm{b}}
$$

Eq. 17 includes the current density, $j$, the mass transport corrected current density, $j_{\mathrm{K}}$, the limiting current density, $j_{\mathrm{L}}$, the exchange current 


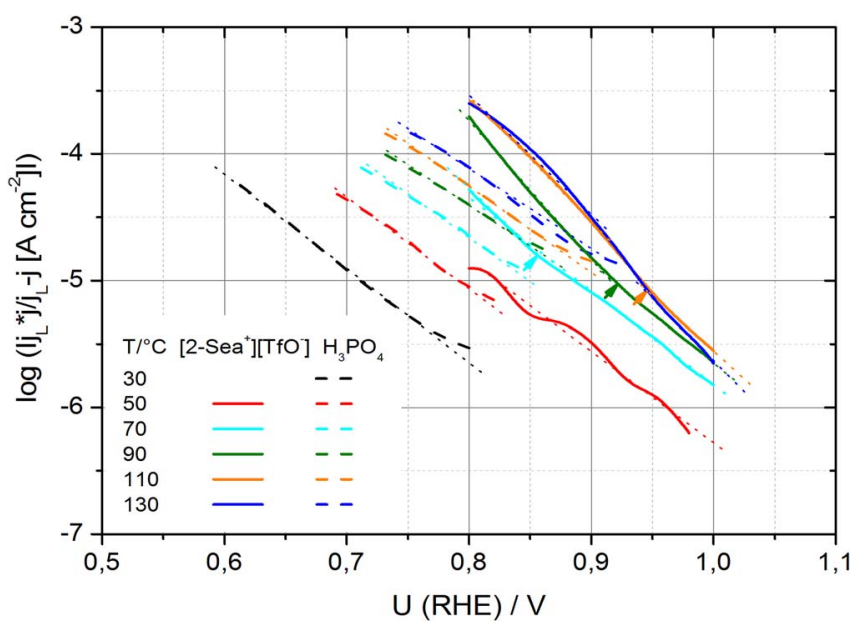

Figure 10. Mass transport corrected Tafel plots of ORR calculated from Fig. 9 b by means of Eq. 17 .

density, $j_{0}$, and the Tafel factor, $b$, given by:

$$
\mathrm{b}=-\frac{2.3 \mathrm{RT}}{\beta_{\mathrm{c}} \mathrm{F}}
$$

For the reaction mechanism proposed above, the cathodic symmetry factor, $\beta_{c}$, can be used instead of the cathodic charge transfer coefficient, $\alpha_{c}{ }^{89}$ From Eq. 18, it follows that under the assumption of $\beta_{c}$ $=0.5, \mathrm{~b}$ values of $120-160 \mathrm{mV}\left(T=30-130^{\circ} \mathrm{C}\right)$ would be expected. However, according to Gottesfeld, ${ }^{90}$ intrinsic and apparent $b$ factors, $b_{\text {int }}$ and $b_{a p p}$, have to be distinguished. The difference becomes clear from the following equation, ${ }^{90}$ which considers the surface coverage of oxygen and intermediates, $\theta_{o x}$, and its dependence on potential.

$$
\frac{\mathrm{d}(\log \mathrm{j})}{\mathrm{d}\left(\mathrm{U}_{0}-\mathrm{U}\right)}=\frac{1}{\mathrm{~b}_{\mathrm{app}}}=\frac{1}{\mathrm{~b}_{\mathrm{int}}}+\frac{1}{1-\theta_{\mathrm{ox}}} \frac{\mathrm{d} \theta_{\mathrm{ox}}}{\mathrm{dU}}
$$

It is evident from Eq. 19 that in the normal case, i.e. $\mathrm{d} \theta_{o x} / \mathrm{d} U>0, b_{a p p}$ is lower than $b_{\text {int }}$. Only at very small coverages $\theta_{o x} \ll 1$ (Langmuir adsorption), does $b_{a p p}$ almost equal $b_{\text {int }}$. A key message of Eq. 19 is that a lower than expected b value (or vice versa, an apparent symmetry factor $\beta_{c}>0.5$ ), i.e. an apparent $b$ factor, can be very well explained by the mechanism proposed in Eqs. 16a-16c. In other words, a change of $b$ factor does not have to mean a change in reaction mechanism, but rather can be referred to as a change in the surface coverage of oxygen and intermediates. Another explanation for apparent $\beta_{c}$ values of $1\left(b=60 \mathrm{mV}\right.$ at $\left.30^{\circ} \mathrm{C}\right)$ has been advanced by Herranz et al. ${ }^{91}$ They showed that in the case of a highly reversible reaction (Eq. 16a), the ORR is a one-electron reaction controlled by the mass transport of oxygen to the electrode surface. It should be mentioned that the 'true' value of the intrinsic $b$ factor of ORR is still under debate and there are good arguments for both $60 \mathrm{mV}^{92}$ and $120 \mathrm{mV}^{93}$ slopes. Pasti et al. conclude that the measured $b$ values give a picture of the state and dynamic processes on the Pt surface rather than the mechanism of ORR. ${ }^{93}$

Mass transport-corrected polarization curves.-Fig. 10 shows the mass transport-corrected Tafel plots of the ORR calculated from the polarization curves presented in Fig. 9. On the basis of the aforementioned factors, the $30^{\circ} \mathrm{C}$ measurement with $\left[2-\mathrm{Sea}^{+}\right]\left[\mathrm{TfO}^{-}\right]$was not considered. Compared to $\mathrm{H}_{3} \mathrm{PO}_{4}$, the Tafel plots obtained with $\left[2-\mathrm{Sea}^{+}\right]\left[\mathrm{TfO}^{-}\right]$are shifted by $30-100 \mathrm{mV}$ to more positive electrode potentials, confirming the superior ORR kinetics in the presence of $\left[2-\mathrm{Sea}^{+}\right]\left[\mathrm{TfO}^{-}\right]$. The potential shift increases with rising temperature and decreasing electrode potential. This is due to a second, steeper slope $\delta j_{K} / \delta U$ for the ORR on $\mathrm{Pt} /\left[2-\mathrm{Sea}^{+}\right]\left[\mathrm{TfO}^{-}\right]$, corresponding to a lower $b$ factor, which starts to develop at $T \geq 70^{\circ} \mathrm{C}$ below a critical potential (indicated by the arrows in Fig. 10) and leads to a growing divergence of the Tafel plots for $\mathrm{H}_{3} \mathrm{PO}_{4}$ and $\left[2-\mathrm{Sea}^{+}\right]\left[\mathrm{TfO}^{-}\right]$with

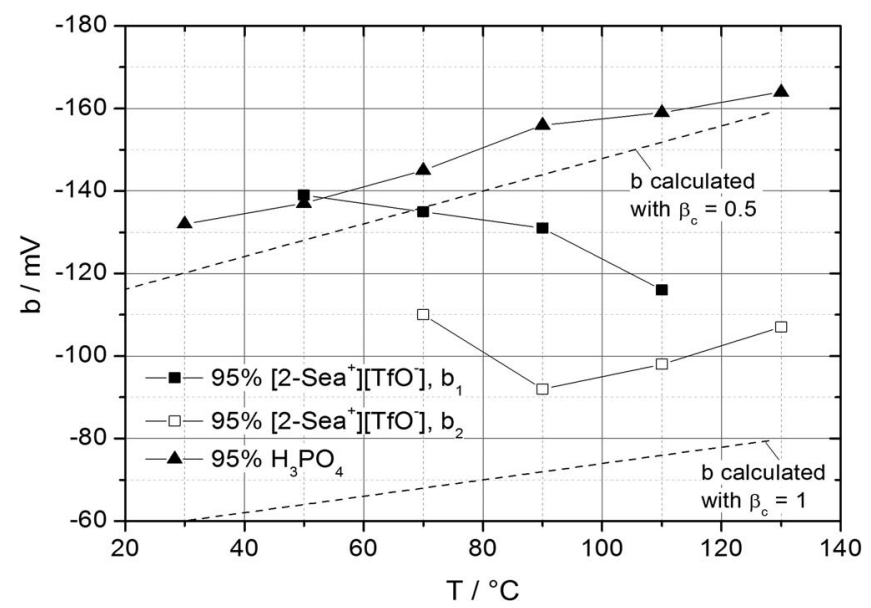

Figure 11. Tafel factors vs. temperature, calculated from Fig. 10 by linear fitting.

decreasing electrode potential. The critical potential increases from about $0.85 \mathrm{~V}\left(70^{\circ} \mathrm{C}\right)$ to $0.95 \mathrm{~V}\left(110^{\circ} \mathrm{C}\right)$. At $130^{\circ} \mathrm{C}$, a critical potential is hardly to be seen. At the same time, the potential range of the first, flatter slope decreases from about $0.15 \mathrm{~V}\left(70^{\circ} \mathrm{C}\right)$ to $0.05 \mathrm{~V}\left(110^{\circ} \mathrm{C}\right)$.

At first glance, a steeper slope $\delta j_{K} / \delta U$ at higher currents seems to contradict the literature's results of the ORR on Pt (see e.g., Damjanovic and Genshaw) ${ }^{94}$ where, conversely, a Tafel factor $b$ of about $-2.3 R T / F\left(\approx-59 \mathrm{mV}\right.$ at $\left.25^{\circ} \mathrm{C}\right)$ is obtained at low current densities and the double value of about $-2 * 2.3 R T / F\left(\approx-118 \mathrm{mV}\right.$ at $\left.25^{\circ} \mathrm{C}\right)$ can be found at high current densities. Damjanovic et al. ${ }^{94}$ explain this behavior by reference to the decreasing coverage of reaction intermediates with rising current density, corresponding to a change from Temkin to Langmuir adsorption. Tarasevich ${ }^{95}$ and Markovic et al., ${ }^{96}$ on the other hand, proposed the blocking of ORR by adsorbed oxygen species like Pt-OH to be responsible for the change to the Tafel slope.

According to Eq. 19, the small, apparent $b$ factor at low current densities results from significant $\theta_{o x}$ coverage caused by water adsorption and the formation of blocking Pt-OH. With increasing cathodic overpotential, i.e., decreasing electrode potential, $\theta_{o x}$ decreases and when it reaches values $<0.1$, the right term in Eq. 19 is negligible and $b_{\text {app }} \approx b_{\text {int }}$. On closer inspection of the ORR Tafel plots presented in the literature, the threshold potential where the Tafel slope changes from -60 to $-120 \mathrm{mV}$ is found to be $<0.8 \mathrm{~V}$, which is smaller than the lower potential limit of the Tafel regime observed with $\left[2-\mathrm{Sea}^{+}\right]\left[\mathrm{TfO}^{-}\right]$. In other words, the limiting ORR current on the static Pt electrode used in this work is too small to reach the potential range of the high (expected) Tafel slope at low electrode potentials. Hence, in this respect, there is no contradiction with the results in the literature. In the following Tafel slope analysis, the parameters $b$ and $\beta_{c}$ obtained with $\left[2-\mathrm{Sea}^{+}\right]\left[\mathrm{TfO}^{-}\right]$above the critical potential (and with $\mathrm{H}_{3} \mathrm{PO}_{4}$ ) will be denoted with a subscript ' 1 ' and those obtained below the critical potential with a subscript ' 2 '. The $b$-factors are plotted in Fig. 11 as a function of temperature and, together with the symmetry factors, are listed in Table II.

In contrast to $\left[2-\mathrm{Sea}^{+}\right]\left[\mathrm{TfO}^{-}\right], \mathrm{H}_{3} \mathrm{PO}_{4}$ reveals only one Tafel slope in the whole ORR potential range, i.e. $b \approx-2 * 2.3 R T / F$ (see Fig. 10). This finding is in accordance with the results obtained in the literature for $98 \mathrm{wt} \% \mathrm{H}_{3} \mathrm{PO}_{4}{ }^{7}$ and is explained by the strong adsorption of phosphate ions onto $\mathrm{Pt}$, even at low potentials and leading to small coverages $\theta_{o x}$. This assumption is supported by measurements of the potential of zero charge (pzc) on a mercury electrode as a function of the $\mathrm{H}_{3} \mathrm{PO}_{4}$ concentration, which revealed a significant decrease in the pzc with the increasing concentration of $\mathrm{H}_{3} \mathrm{PO}_{4} .{ }^{5}$ The increase of the $b$ factor with rising temperature is in qualitative accordance with Eq. 18, which predicts a linear relationship between $b$ and $T$. A linear increase of $b$ vs. $T$ has also been reported for $98 \mathrm{wt} \% \mathrm{H}_{3} \mathrm{PO}_{4}$ by Scharifker et al. ${ }^{7}$ Hence, the symmetry factor $\beta_{c l}$ of $0.46-0.49$ is largely independent of temperature (see Fig. 11 and Table II). 
Table II. Results of the analysis of the mass transport corrected Tafel plots shown in Fig. 10.

\begin{tabular}{|c|c|c|c|c|c|c|c|c|}
\hline \multirow[b]{2}{*}{$\mathrm{T} /{ }^{\circ} \mathrm{C}$} & \multicolumn{2}{|c|}{$-b_{1} / m V$} & \multicolumn{2}{|l|}{$\beta_{\mathrm{c} 1} /-$} & \multirow{2}{*}{$\begin{array}{c}-\mathrm{b}_{2} / \mathrm{mV} \\
{\left[2-\mathrm{Sea}^{+}\right]\left[\mathrm{TfO}^{-}\right]}\end{array}$} & \multirow{2}{*}{$\begin{array}{c}\beta_{\mathrm{c} 2} /- \\
{\left[2-\mathrm{Sea}^{+}\right]\left[\mathrm{TfO}^{-}\right]}\end{array}$} & \multicolumn{2}{|c|}{$\mathrm{E}_{\mathrm{a}}\left(\mathrm{J}_{\mathrm{U}}=0.8 \mathrm{~V}\right) / \mathrm{kJ} \mathrm{mol}^{-1}$} \\
\hline & {$\left[2-\mathrm{Sea}^{+}\right]\left[\mathrm{TfO}^{-}\right]$} & $\mathrm{H}_{3} \mathrm{PO}_{4}$ & {$\left[2-\mathrm{Sea}^{+}\right]\left[\mathrm{TfO}^{-}\right]$} & $\mathrm{H}_{3} \mathrm{PO}_{4}$ & & & {$\left[2-\mathrm{Sea}^{+}\right]\left[\mathrm{TfO}^{-}\right]$} & $\mathrm{H}_{3} \mathrm{PO}_{4}$ \\
\hline 30 & - & 132 & - & 0.46 & - & & - & \\
\hline 70 & 135 & 145 & 0.50 & 0.47 & 110 & 0.62 & & \\
\hline 90 & 131 & 156 & 0.55 & 0.46 & 92 & 0.78 & & \\
\hline 110 & 116 & 159 & 0.65 & 0.48 & 98 & 0.77 & 8.9 & 20.7 \\
\hline 130 & - & 164 & $\longrightarrow$ & 0.49 & 107 & 0.75 & & \\
\hline
\end{tabular}

In the case of $\left[2-\mathrm{Sea}^{+}\right]\left[\mathrm{TfO}^{-}\right]$, the second Tafel slope evolving for temperatures $\geq 70^{\circ} \mathrm{C}$ could be associated with a decreasing coverage of $\left[\mathrm{TfO}^{-}\right]$anions and $\left[2-\mathrm{Sea}^{+}\right]$cations, as discussed in Cyclic voltammetry section. At the same time, the coverage of water, oxygen and its intermediates would increase from small values $\left(\theta_{o x} \ll 1, b \approx\right.$ $-2.3 R T /(0.5 F)$, Langmuir adsorption) to medium values $\left(\theta_{o x}>0.1\right.$, $b<-2.3 R T /(0.5 F)$, Temkin adsorption). The $b_{1}$ factor of ORR in the presence of $95 \mathrm{wt} \%\left[2-\mathrm{Sea}^{+}\right]\left[\mathrm{TfO}^{-}\right]$decreases with rising temperature, whereas $b_{2}$ exhibits a minimum of $90^{\circ} \mathrm{C}$ (see Fig. 11). The negative slopes of $b$ vs. $T$ for various reactions, e.g., the hydrogen evolution reaction on $\mathrm{Pt}$ in methanolic $\mathrm{HCl}$ solutions, were already reported by Conway et al. in $1970 .{ }^{97}$ Depending on the electrode / electrolyte system, Conway et al. explained the anomalous temperature dependence of $b$ with the specific adsorption of anions, solvent structure effects on the double-layer and atomic hydrogen coverage effects. It should be kept in mind that the double layer properties of a Pt/PIL interface like Pt/[2-Sea $\left.{ }^{+}\right]\left[\mathrm{TfO}^{-}\right]$, including the specific adsorption of cations and anions, may significantly differ from that of the $\mathrm{Pt} / \mathrm{H}_{3} \mathrm{PO}_{4}$ interface, as discussed in Cyclic voltammetry section.

The decrease of $b_{1}$ corresponds to an increase in $\beta_{c l}$ (see Eq. 20). For temperatures up to $90^{\circ} \mathrm{C}$, this means that values around 0.5 for $\beta_{c l}$, similar to the observations of $\mathrm{H}_{3} \mathrm{PO}_{4}$, suggest small oxygen / intermediate coverage (see Table II). Above $90^{\circ} \mathrm{C}, \beta_{c l}$ increases to a value of $0.65\left(110^{\circ} \mathrm{C}\right.$, see Table II), which is most likely an apparent value caused by the beginning of interference from Pt oxidation. Analogous to the explanation given above, the maximum of $\beta_{c 2}=0.78$ at $90^{\circ} \mathrm{C}$ correlates with a maximum of oxygen / intermediate coverage. The decrease of $\beta_{c 2}$ at temperatures above $90^{\circ} \mathrm{C}$, which means a decrease of $\theta_{o x}$, may be explained by an increasing adsorption of water that leads to the formation of blocking Pt-OH at ever lower electrode potentials.

Activation energy of the ORR.-Finally, the apparent activation energies of the current density were calculated. Apparent activation energies are often calculated from the exchange current densities at the corresponding equilibrium potentials. However, most of these results were obtained by RDE experiments, with the Tafel regimes covering a current range of several orders of magnitude and a potential range of several hundred $\mathrm{mV}$. As shown in Fig. 10, the calculation of exchange current densities of the ORR on a static Pt electrode (especially in the case of $\left[2-\mathrm{Sea}^{+}\right]\left[\mathrm{TfO}^{-}\right]$) would require the extrapolation of relatively narrow linear potential regimes over several hundred $\mathrm{mV}$ with regard to equilibrium potentials of about 1.2-1.3 V, which does not seem to be reliable. We therefore decided to only determine the apparent activation energies of the ORR at an electrode potential of $0.8 \mathrm{~V}$. This potential is close to or within the Tafel regimes of both $\left[2-\mathrm{Sea}^{+}\right]\left[\mathrm{TfO}^{-}\right]$and $\mathrm{H}_{3} \mathrm{PO}_{4}$ and a representative for the operation of HT-PEFC cathodes.

As is shown in Fig. 12, the Arrhenius plots of ORR current densities on $\mathrm{Pt}$ in the presence of $95 \mathrm{wt} \%\left[2-\mathrm{Sea}^{+}\right]\left[\mathrm{TfO}^{-}\right]$and $95 \mathrm{wt} \% \mathrm{H}_{3} \mathrm{PO}_{4}$ reveal a threshold of $90^{\circ} \mathrm{C}$. There is high apparent activation energy $\mathrm{E}_{\mathrm{a}}$ below $90^{\circ} \mathrm{C}$ and with low values above $90^{\circ} \mathrm{C}$. In the case of $\mathrm{H}_{3} \mathrm{PO}_{4}$, the apparent decrease of activation energy from about $40 \mathrm{~kJ} / \mathrm{mol}(T \leq$ $\left.90^{\circ} \mathrm{C}\right)$ to $21 \mathrm{~kJ} / \mathrm{mol}\left(T \geq 90^{\circ} \mathrm{C}\right)$ may be caused by the increasing surface blocking effect of impurities like phosphorous acid (see Fig. 6b and Cyclic voltammetry section). Another reason for the $90^{\circ} \mathrm{C}$ threshold could be the abovementioned anomalous behavior of oxygen solubility in concentrated phosphoric acid ${ }^{7,80}$ : if the oxygen solubility stops increasing at $T>97^{\circ} \mathrm{C}$, this might well explain the relatively small increase in current at elevated temperatures. Both effects would lead to a smaller increase in current density at elevated temperatures. The value of about $40 \mathrm{~kJ} / \mathrm{mol}$ for $T \leq 90^{\circ} \mathrm{C}$ lies within the range of $40-72$ $\mathrm{kJ} \mathrm{mol}^{-1}$ reported in the literature. ${ }^{7,98-100}$

In the presence of $\left[2-\mathrm{Sea}^{+}\right]\left[\mathrm{TfO}^{-}\right]$, the apparent activation energy decreases dramatically from about $68 \mathrm{~kJ} \mathrm{~mol}^{-1}\left(T<90^{\circ} \mathrm{C}\right)$ to $9 \mathrm{~kJ}$ $\mathrm{mol}^{-1}\left(T>90^{\circ} \mathrm{C}\right)$. In theory, the same factors could be responsible for this effect as those discussed in the last paragraph. However, such an explanation would be rather speculative, as the used TFMSA was not analyzed and oxygen solubility in $\left[2-\mathrm{Sea}^{+}\right]\left[\mathrm{TfO}^{-}\right]$is unknown. Nevertheless, the high $E_{a}$ value for the low temperature region can be easily explained through the evolution of a second Tafel slope, which leads to higher current densities at $T \geq 70^{\circ} \mathrm{C}$ (see Fig. 10). The small $E_{a}$ value calculated for elevated temperatures requires a more detailed examination. Small or even negative apparent activation energies have been reported by Kirowa-Eisner et al. for the reduction of $\mathrm{BrO}_{3}{ }^{-}$. Their general explanation for the origin of the apparent negative activation energies is an adsorption step (chemical equilibrium) prior to the ratedetermining (charge transfer) step. In the case of ORR, this would be the oxygen adsorption preceding the first reduction step (see Eq. 16a). Thus, the apparent electrochemical activation enthalpy would be the sum of the adsorption enthalpy and the activation enthalpy of the rate-determining step.

The negative values of the resulting apparent electrochemical enthalpy of activation are obtained if the positive value of the activation enthalpy of the rate-determining step is overcompensated by a negative adsorption enthalpy. This means that with increasing temperature, the surface coverage of oxygen and intermediates would decrease faster than the constant rate of ORR increases as a result of the increasing

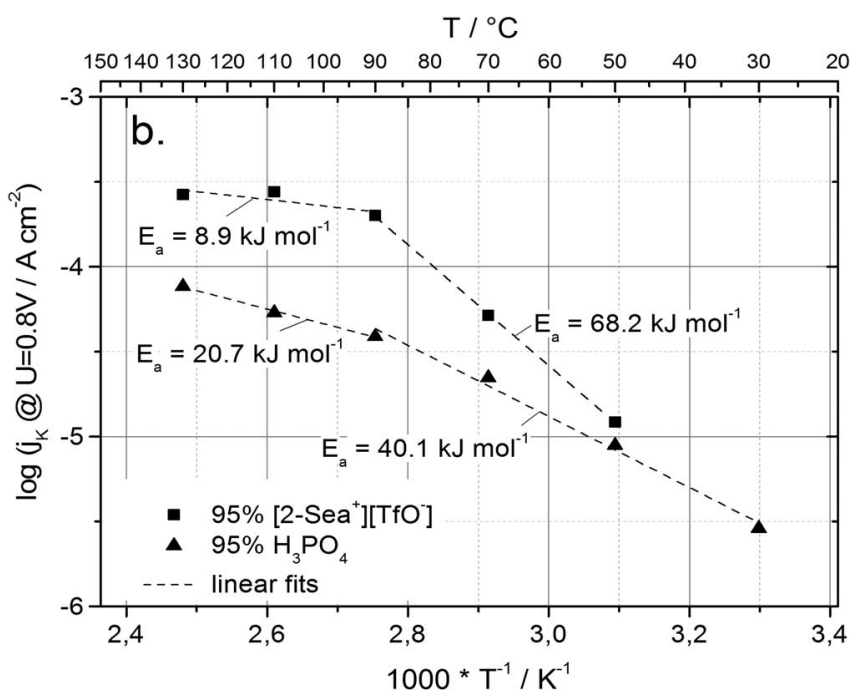

Figure 12. Arrhenius plots of ORR current densities at $U=800 \mathrm{mV}$, data taken from Fig. 10, apparent activation energies indicated in the diagram were calculated by linear fitting. 
adsorption of water and growing blocking effect of Pt-OH. A decrease of oxygen adsorption at $T>90^{\circ} \mathrm{C}$ does not necessarily mean very low $\theta_{o x}$ values, implying that it need not be contradictory with respect to Temkin adsorption. Moreover, the assumption of a decrease in $\theta_{o x}$ is in accordance with the decrease of $\beta_{c 2}$ at elevated temperatures. In any case, a compensation effect of decreasing oxygen adsorption and increasing ORR rate constant would explain both the reduced apparent activation energy and the similar $U / I$ curves obtained at 110 and $130^{\circ} \mathrm{C}$.

Based on the work carried out so far, the following picture emerges for the system $\mathrm{Pt} / 95 \mathrm{wt} \%\left[2-\mathrm{Sea}^{+}\right]\left[\mathrm{TfO}^{-}\right]$: At low temperatures, large parts of the $\mathrm{Pt}$ surface are blocked by $\left[2-\mathrm{Sea}^{+}\right]\left[\mathrm{TfO}^{-}\right]$. Thus, the oxygen / intermediate coverage is small and $b$ values in the range of $120 \mathrm{mV}$ are obtained (Langmuir adsorption). When heated up to $90^{\circ} \mathrm{C}$, the $\left[2-\mathrm{Sea}^{+}\right]\left[\mathrm{TfO}^{-}\right]$layer on the Pt surface becomes more and more disordered and the number of free active sites for oxygen adsorption increases. At the same time, $\theta_{o x}$ increases, indicating a Temkin adsorption, which is associated with smaller $b$ factors. At temperatures $\geq 90^{\circ} \mathrm{C}$, the increasing adsorption of water causes an ever stronger blocking of oxygen adsorption by $\mathrm{Pt}-\mathrm{OH}$, which may explain the $90^{\circ} \mathrm{C}$ threshold found for the apparent activation energy. However, the above-mentioned considerations should by no means be regarded as conclusive. They represent, rather, a first, tentative model to describe the temperature and potential dependent ORR kinetics on polycrystalline $\mathrm{Pt}$ in the presence of an ionic liquid with a small amount of water.

\section{Conclusions}

2-Sulfoethylammonium trifluoromethanesulfonate [2-Sea $\left.{ }^{+}\right]$ $\left[\mathrm{TfO}^{-}\right]$represents a novel class of strongly acidic proton-conducting ionic liquids (PILs) based on aminoalkylsulfonic acids. It has proven its potential as an electrolyte in high temperature PEM fuel cells (HT-PEFCs). [2-Sea $\left.{ }^{+}\right]\left[\mathrm{TfO}^{-}\right]$and phosphoric acid, the state-ofthe-art electrolyte in HT-PEFCs, were compared regarding their physico-chemical properties and their influence on the kinetics of the oxygen reduction reaction (ORR) using polycrystalline platinum electrodes. $5 \mathrm{wt} \%$ of water were added to both electrolytes, which is a typical water content achieved under HT-PEFC operation. The most important results are as follows:

(i) the electrochemical stability of $\left[2-\mathrm{Sea}^{+}\right]\left[\mathrm{TfO}^{-}\right]$over the whole potential range relevant for fuel cell application

(ii) superior ORR kinetics on $\mathrm{Pt}$ with $95 \mathrm{wt} \%\left[2-\mathrm{Sea}^{+}\right]\left[\mathrm{TfO}^{-}\right]$ compared to $95 \mathrm{wt} \% \mathrm{H}_{3} \mathrm{PO}_{4}$ at temperatures $\geq 90^{\circ} \mathrm{C}$ in the application-relevant potential range

(iii) temperature-dependent ORR kinetics on $\mathrm{Pt}$ with $95 \mathrm{wt} \%$ $\left[2-\mathrm{Sea}^{+}\right]\left[\mathrm{TfO}^{-}\right]$can be explained by a competitive coverage of $\left[2-\mathrm{Sea}^{+}\right]\left[\mathrm{TfO}^{-}\right]$and water

(iv) the thermal stability of $\left[2-\mathrm{Sea}^{+}\right]\left[\mathrm{TfO}^{-}\right]$up to $140^{\circ} \mathrm{C}$

(v) the specific conductivity of $95 \mathrm{wt} \%\left[2-\mathrm{Sea}^{+}\right]\left[\mathrm{TfO}^{-}\right]$about one order of magnitude lower compared to $95 \mathrm{wt} \% \mathrm{H}_{3} \mathrm{PO}_{4}$ at $130^{\circ} \mathrm{C}$

(vi) the strong coupling of specific conductivity and dynamic viscosity indicates vehicular proton transport in $95 \mathrm{wt} \%$ $\left[2-\mathrm{Sea}^{+}\right]\left[\mathrm{TfO}^{-}\right]$

The results of the electrochemical investigations carried out so far do not allow definitive conclusions regarding the kinetics of ORR on $\mathrm{Pt}$ in the presence of $\left[2-\mathrm{Sea}^{+}\right]\left[\mathrm{TfO}^{-}\right]$and the double layer properties of the $\mathrm{Pt} /\left[2-\mathrm{Sea}^{+}\right]\left[\mathrm{TfO}^{-}\right]$interface to be drawn. However, a preliminary model was presented which implies that the structures of $\left[2-\mathrm{Sea}^{+}\right]\left[\mathrm{TfO}^{-}\right]$adsorbed on Pt or near the Pt surface become more and more disordered with rising temperatures and the adsorption of water molecules plays an important role in the double layer processes, especially at elevated temperatures.

Future investigations are therefore necessary. In particular, the specific conductivity and thermal stability of the ionic liquid has to be enhanced, e.g., by using N-substituted or homologous aminoalkylsulfonic acids. Moreover, a more detailed analysis of the double layer properties of the $\mathrm{Pt} /\left[2-\mathrm{Sea}^{+}\right]\left[\mathrm{TfO}^{-}\right]$interface is essential to understanding the potential and temperature-dependence of ORR kinetics. Rotating disk experiments at elevated temperatures above $100^{\circ} \mathrm{C}$ are also necessary to extend the knowledge of the ORR kinetics over a larger range of current density and to determine oxygen diffusivity and concentration. Another aspect is the detailed knowledge of the partial pressure of water in the vapor phase in equilibrium with the ionic liquid. Such data would be desirable for a better comparison of different electrolytes (ionic liquids). Finally, membranes and MEAs based on PBI have to be prepared and characterized in order to prove the applicability of this new class of PILs under HT-PEFC operation conditions.

\section{Acknowledgments}

We gratefully acknowledge the development and construction of the PIL test cell by K. Klafki, R. Reichel and M. Lothmann. We are obliged to M. Drüschler for valuable comments and suggestions on the influence of temperature on the differential double layer capacitance.

\section{References}

1. J. C. Huang, R. K. Sen, and E. Yeager, Journal of The Electrochemical Society, 126, 786 (1979).

2. W. E. O'Grady, E. J. Taylor, and S. Srinivasan, Journal of Electroanalytical Chemistry and Interfacial Electrochemistry, 132, 137 (1982).

3. K. L. Hsueh, E. R. Gonzalez, and S. Srinivasan, Electrochimica Acta, 28, 691 (1983).

4. P. N. Ross and P. C. Andricacos, Journal of Electroanalytical Chemistry and Interfacial Electrochemistry, 154, 205 (1983).

5. K. L. Hsueh, E. R. Gonzalez, S. Srinivasan, and D. T. Chin, Journal of The Electrochemical Society, 131, 823 (1984).

6. M. M. Ghoneim, S. Clouser, and E. Yeager, Journal of The Electrochemical Society, 132, 1160 (1985)

7. B. R. Scharifker, P. Zelenay, and J. O. M. Bockris, Journal of The Electrochemical Society, 134, 2714 (1987).

8. J. T. Glass, G. L. Cahen, and G. E. Stoner, Journal of The Electrochemical Society, 136, 656 (1989).

9. J. B. Floriano, E. A. Ticianelli, and E. R. Gonzalez, Journal of Electroanalytical Chemistry, 367, 157 (1994).

10. N. Sugishima, J. T. Hinatsu, and F. R. Foulkes, Journal of The Electrochemical Society, 141, 3332 (1994)

11. A. Tanaka, R. Adžić, and B. Nikolić, J. Serb. Chem. Soc., 64, 695 (1999).

12. Z. Liu, J. S. Wainright, M. H. Litt, and R. F. Savinell, Electrochimica Acta, 51, 3914 (2006).

13. Q. He, X. Yang, W. Chen, S. Mukerjee, B. Koel, and S. Chen, Phys. Chem. Chem. Phys., 12, 12544 (2010)

14. Q. He, B. Shyam, M. Nishijima, D. Ramaker, and S. Mukerjee, J. Phys. Chem. C, 117, 4877 (2013)

15. S. Kaserer, K. M. Caldwell, D. E. Ramaker, and C. Roth, J. Phys. Chem. C, 117, 6210 (2013)

16. S. J. Buelte, D. Lewis, and G. Eisman, ECS Transactions, 41, 1955 (2011).

17. A. Orfanidi, M. K. Daletou, L. Sygellou, and S. G. Neophytides, J. Appl. Electrochem., 43, 1101 (2013).

18. M. C. Santos, D. W. Miwa, and S. A. S. Machado, Electrochemistry Communications, 2, 692 (2000)

19. W. M. Vogel and J. M. Baris, Electrochimica Acta, 23, 463 (1978).

20. M. Weber, F. C. Nart, I. R. de Moraes, and T. Iwasita, The Journal of Physical Chemistry, 100, 19933 (1996).

21. S. Ye, H. Kita, and A. Aramata, Journal of Electroanalytical Chemistry, 333, 299 (1992).

22. J.-R. Kim, J. S. Yi, and T.-W. Song, Journal of Power Sources, 220, 54 (2012).

23. V. S. Bagotzky, Y. B. Vassilyev, J. Weber, and J. N. Pirtskhalava, Journal of Electroanalytical Chemistry and Interfacial Electrochemistry, 27, 31 (1970).

24. L. Qingfeng, X. Gang, H. A. Hjuler, R. W. Berg, and N. J. Bjerrum, Journal of The Electrochemical Society, 142, 3250 (1995).

25. M. A. Habib and J. O. M. Bockris, Journal of The Electrochemical Society, 130, 2510 (1983).

26. M. A. Habib and J. O. M. Bockris, Journal of The Electrochemical Society, 132, 108 (1985)

27. F. C. Nart and T. Iwasita, Electrochimica Acta, 37, 385 (1992).

28. G. Horányi, E. M. Rizmayer, and G. Inzelt, Journal of Electroanalytical Chemistry and Interfacial Electrochemistry, 93, 183 (1978).

29. P. Zelenay, B. R. Scharifker, J. O. M. Bockris, and D. Gervasio, Journal of The Electrochemical Society, 133, 2262 (1986).

30. V. S. Murthi, R. C. Urian, and S. Mukerjee, J. Phys. Chem. B, 108, 11011 (2004).

31. M. Mamlouk, P. Ocon, and K. Scott, J. Power Sources, 245, 915 (2014).

32. S.-Y. Lee, T. Yasuda, and M. Watanabe, J. Power Sources, 195, 5909 (2010).

33. A. Noda, M. A. B. H. Susan, K. Kudo, S. Mitsushima, K. Hayamizu, and M. Watanabe, J. Phys. Chem. B, 107, 4024 (2003). 
34. S.-Y. Lee, A. Ogawa, M. Kanno, H. Nakamoto, T. Yasuda, and M. Watanabe, J. Am. Chem. Soc., 132, 2183 (2010).

35. T. Yasuda and M. Watanabe, MRS Bull., 38, 560 (2013).

36. K. D. Kreuer, A. Rabenau, and W. Weppner, Angew. Chem., 94, 224 (1982).

37. J.-P. Belieres, D. Gervasio, and C. A. Angell, Chemical Communications, 4799 (2006).

38. R. Hagiwara, T. Nohira, K. Matsumoto, and Y. Tamba, Electrochem. Solid-State Lett., 8, A231 (2005)

39. P. Kiatkittikul, T. Nohira, and R. Hagiwara, J. Power Sources, 220, 10 (2012).

40. S. Y. Kim, S. Kim, and M. J. Park, Nat. Commun., 1, Kim1/1 (2010).

41. S.-Y. Lee, A. Ogawa, M. Kanno, H. Nakamoto, T. Yasuda, and M. Watanabe, J Am Chem Soc, 132, 9764 (2010).

42. S. S. Sekhon, B. S. Lalia, J.-S. Park, C.-S. Kim, and K. Yamada, J. Mater Chem., 16, 2256 (2006)

43. S. S. Sekhon, P. Krishnan, B. Singh, K. Yamada, and C. S. Kim, Electrochim. Acta, 52, 1639 (2006)

44. M. A. B. H. Susan, A. Noda, S. Mitsushima, and M. Watanabe, Chem. Commun (Cambridge, U. K.), 938 (2003).

45. E. van de Ven, A. Chairuna, G. Merle, S. P. Benito, Z. Borneman, and K. Nijmeijer, J. Power Sources, 222, 202 (2013).

46. S.-Y. Lee, T. Yasuda, and M. Watanabe, J. Power Sources, 195, 5909 (2010).

47. J. G. Jacobsen and L. H. Smith, Physiological Reviews, 48, 424 (1968).

48. C. E. Wright, H. H. Tallan, Y. Y. Lin, and G. E. Gaull, Annu. Rev. Biochem., 55, 427 (1986).

49. M. Hopfinger, K. Lux, F. Schubert, and A. Kornath, Acta Cryst. C, 67, m400 (2011).

50. W. Maier, Phosphorsäureverteilung in Membran-Elektroden-Einheiten dynamisch betriebener Hochtemperatur-Polymerelektrolyt-Brennstoffzellen, in, p. 105, Jülich (2013).

51. S. B. Brummer, J. Phys. Chem., 69, 562 (1965).

52. J. P. Hoare, Gen. Motors Eng. J., 9, 14 (1962).

53. M. Fleischmann and J. N. Hiddleston, J. Sci. Instrum., [2]1, 667 (1968).

54. M. J. Vasile and C. G. Enke, J. Electrochem. Soc., 112, 865 (1965)

55. J. V. Dobson, Journal of Electroanalytical Chemistry and Interfacial Electrochemistry, 35, 129 (1972).

56. J. V. Dobson, B. R. Chapman, and H. R. Thirsk, Int. Corros. Conf. Ser., NACE-4 341 (1976).

57. R. J. Ratchford and G. W. Castellan, J. Phys. Chem., 62, 1123 (1958).

58. T. B. Flanagan and F. A. Lewis, Trans. Faraday Soc., 55, 1400 (1959).

59. C. Korte, in Fuel Cell Science and Engineering, p. 335, Wiley-VCH Verlag GmbH \& Co. KGaA (2012).

60. D.-T. Chin and H. Chang, J Appl Electrochem, 19, 95 (1989).

61. N. Sugishima, J. T. Hinatsu, and F. R. Foulkes, Journal of The Electrochemical Society, 141, 3325 (1994).

62. H. A. Laitinen and C. G. Enke, J. Electrochem. Soc., 107, 773 (1960)

63. K. J. Vetter, Z. Elektrochem. Angew. Phys. Chem., 62, 642 (1958).

64. V. A. Sethuraman and J. W. Weidner, Electrochim. Acta, 55, 5683 (2010).

65. O. Stern, Z. Elektrochem. Angew. Phys. Chem., 30, 508 (1924).

66. V. Lockett, M. Horne, R. Sedev, T. Rodopoulos, and J. Ralston, Phys. Chem. Chem Phys., 12, 12499 (2010).
67. W. Maier, T. Arlt, K. Wippermann, C. Wannek, I. Manke, W. Lehnert, and D. Stolten, ECS Transactions, 41, 1413 (2011).

68. M. Drueschler, N. Borisenko, J. Wallauer, C. Winter, B. Huber, F. Endres, and B. Roling, Phys. Chem. Chem. Phys., 14, 5090 (2012).

69. J. O. M. Bockris and A. K. N. Reddy, Modern Electrochemistry, an Introduction to an Interdisciplinary Area, Vol. 1, p. 622 pp., Macdonald (1970).

70. R. A. Munson, J. Chem. Phys., 40, 2044 (1964).

71. H. Weingaertner, Z. Phys. Chem. (Muenchen, Ger.), 220, 1395 (2006).

72. B. E. Conway, J. O. M. Bockris, and I. A. Ammar, Trans. Faraday Soc., 47, 756 (1951).

73. R. J. Macdonald and C. A. Barlow Jr., J. Chem. Phys., 36, 3062 (1962).

74. A. A. Kornyshev, J. Phys. Chem. B, 111, 5545 (2007).

75. A. Lewandowski, M. Galinski, and S. R. Krajewski, Z. Naturforsch., A: Phys. Sci., 62, 187 (2007)

76. H. Wroblowa, M. L. B. Rao, A. Damjanovic, and J. O. M. Bockris, J. Electroanal Chem. Interfacial Electrochem., 15, 139 (1967).

77. X.-J. Huang, E. I. Rogers, C. Hardacre, and R. G. Compton, J. Phys. Chem. B, 113 8953 (2009)

78. R. Condemarin and P. Scovazzo, Chem. Eng. J. (Amsterdam, Neth.), 147, 51 (2009).

79. P. K. Kilaru and P. Scovazzo, Ind. Eng. Chem. Res., 47, 910 (2008)

80. K. Klinedinst, J. A. S. Bett, J. Macdonald, and P. Stonehart, Journal of Electroanalytical Chemistry and Interfacial Electrochemistry, 57, 281 (1974).

81. J. C. Huang, R. K. Sen, and E. Yeager, J. Electrochem. Soc., 126, 786 (1979).

82. D. A. Walsh, A. Ejigu, J. Smith, and P. Licence, Phys Chem Chem Phys, 15, 7548 (2013).

83. A. J. Appleby and B. S. Baker, J. Electrochem. Soc., 125, 404 (1978).

84. A. Damjanovic, D. B. Sepa, and M. V. Vojnovic, Electrochim. Acta, 24, 887 (1979).

85. P. N. Ross and P. C. Andricacos, J. Electroanal. Chem. Interfacial Electrochem., 154, 205 (1983).

86. D. B. Sepa, M. V. Vojnovic, L. M. Vracar, and A. Damjanovic, Electrochim. Acta 32, 129 (1987)

87. E. E. Switzer, R. Zeller, Q. Chen, K. Sieradzki, D. A. Buttry, and C. Friesen, J. Phys. Chem. C, 117, 8683 (2013).

88. J. W. Schultze and K. Wippermann, Electrochimica Acta, 32, 823 (1987).

89. R. Guidelli, R. G. Compton, J. M. Feliu, E. Gileadi, J. Lipkowski, W. Schmickler, and S. Trasatti, Pure Appl. Chem., 86, 245 (2014).

90. S. Gottesfeld, ECS Trans., 6, 51 (2008).

91. J. Herranz, A. Garsuch, and H. A. Gasteiger, The Journal of Physical Chemistry C, 116, 19084 (2012)

92. M. Arenz and N. M. Markovic, in, p. 283 (2010).

93. I. A. Pasti, N. M. Gavrilov, and S. V. Mentus, Int. J. Electrochem. Sci., 7, 11076 (2012)

94. A. Damjanovic and M. A. Genshaw, Electrochim. Acta, 15, 1281 (1970).

95. M. R. Tarasevich, Elektrokhimiya, 9, 599 (1973).

96. N. M. Markovic, R. R. Adzic, B. D. Cahan, and E. B. Yeager, J. Electroanal. Chem., 377, 249 (1994).

97. B. E. Conway, D. J. MacKinnon, and B. V. Tilak, Trans. Faraday Soc., 66, 1203 (1970).

98. A. Essalik, O. Savadogo, and F. Ajersch, J. Electrochem. Soc., 142, 1368 (1995)

99. A. J. Appleby, J. Electroanal. Chem. Interfacial Electrochem., 24, 97 (1970).

100. K. Scott and M. Mamlouk, Proc. Inst. Mech. Eng., Part A, 225, 161 (2011). 